\title{
Atomic Force Microscopy investigations on pits and debris related to fretting- corrosion between 316L SS and PMMA.
}

\author{
J. Geringer ${ }^{1,2}$, J. Pellier ${ }^{1}$, F. Cleymand ${ }^{3}$, B. Forest ${ }^{1}$ \\ ${ }^{1}$ Ecole Nationale Supérieure des Mines, CIS-EMSE, CNRS:UMR5146, LCG, \\ F-42023 Saint-Etienne de Saint-Etienne \\ geringer@emse.fr corresponding author, Ph: +33 477426 688; Fax: +33 477421057 \\ ${ }^{2}$ Penn State University Materials Science and Engineering \\ Center for Electrochemical Science and Technology \\ 206A Steidle building University Park 16802 PA USA \\ jag54@psu.edu, Ph : 0018148638378 \\ ${ }^{3}$ Institut Jean Lamour, UMR CNRS 7198 \\ Ecole Nationale Supérieure des Mines de Nancy (ENSM-N), \\ Parc de Saurupt, CS 14234, 54042 NANCY cedex, France \\ franck.cleymand@ijl.nancy-universite.fr
}

\begin{abstract}
In the case of hip prostheses, debris generation, due to the fretting-corrosion phenomenon between the femoral stem and the bone cement is one of the most significant causes of reintervention. In this study we use Atomic Force Microscopy (AFM) to analyze PMMA particles and pitting corrosion on 316L $\mathrm{SS}$ as a function of chlorides and albumin concentration. Without albumin, the number of pits increases with the chlorides concentration. Contrary to the protective effect of albumin on global corrosive wear, albumin tends to increases the number of pits. The number of ejected particles highly depends on electrochemical conditions and the in vivo conditions, Open Circuit Potential, seem to lead to a small number of particles. This work has also explored atomic force microscopy as a "new" characterization technique for wear debris and demonstrates that $80 \%$ of particles have a size inferior to $100 \mathrm{~nm}$, which is the 'critical size' for tissues response.
\end{abstract}

Keywords: fretting-corrosion, hip implants, 316L SS, PMMA, debris, AFM. 


\section{Introduction}

In the world, about 1.5 million hip prostheses are implanted each year. Because of the ageing of the population, this number will continue to increase. Moreover, roughly $10 \%$ of Total Hip Arthroplasties (THA) lead to a surgical reoperation after 10-15 years [1]. To prevent another intervention, studies about the improvement of lifetime duration of orthopedic implants are relevant.

In 1960's, Sir John Charnley chose to insert hip prostheses with bone cement (based on poly(methyl methacrylate) composition), to decrease the number of femoral stem debonding [2]. In the case of cemented prostheses (Figure 1), the femoral stem is commonly in austenitic Stainless Steel: 316L SS

Due to the human activity and the significant differences of mechanical properties between $316 \mathrm{~L}$ SS and bone cement, debonding between these two materials may occur. This phenomenon, due to stress shielding, leads to friction between femoral stem and bone cement. Cracks can appear in the bone cement layer and can progress into it (Figure 1). Physiological liquid, carrying metal and bone cement debris and metal ions, reaches to bone tissues and causes the tissues inflammation [3]. Debris disturb osteoblasts cells (reconstructive cells of the bone) activity and leads to osteolysis (bone destruction) and thus to prostheses outplacing [4].

Due to fretting-corrosion (friction under small displacements in a corrosive medium) between femoral stem and bone cement, two types of debris are produced: metallic oxides and bone cement particles. Several studies show that debris size, composition, shape and concentration are the most influential on debris bioreactivity [5,6]. Due to their biocompatibility and high resistance against corrosion in biological environment, materials like 316L stainless steel or PMMA (bone cement), are often implanted. However, the inertness of these materials is relative: in the form of fine powders these materials may cause tissues reactions [7]. For example Escalas et al. showed that materials in solid form are surrounded by a variable inflammatory infiltrate although materials in powder form are surrounded by a considerable inflammatory infiltrate [8].

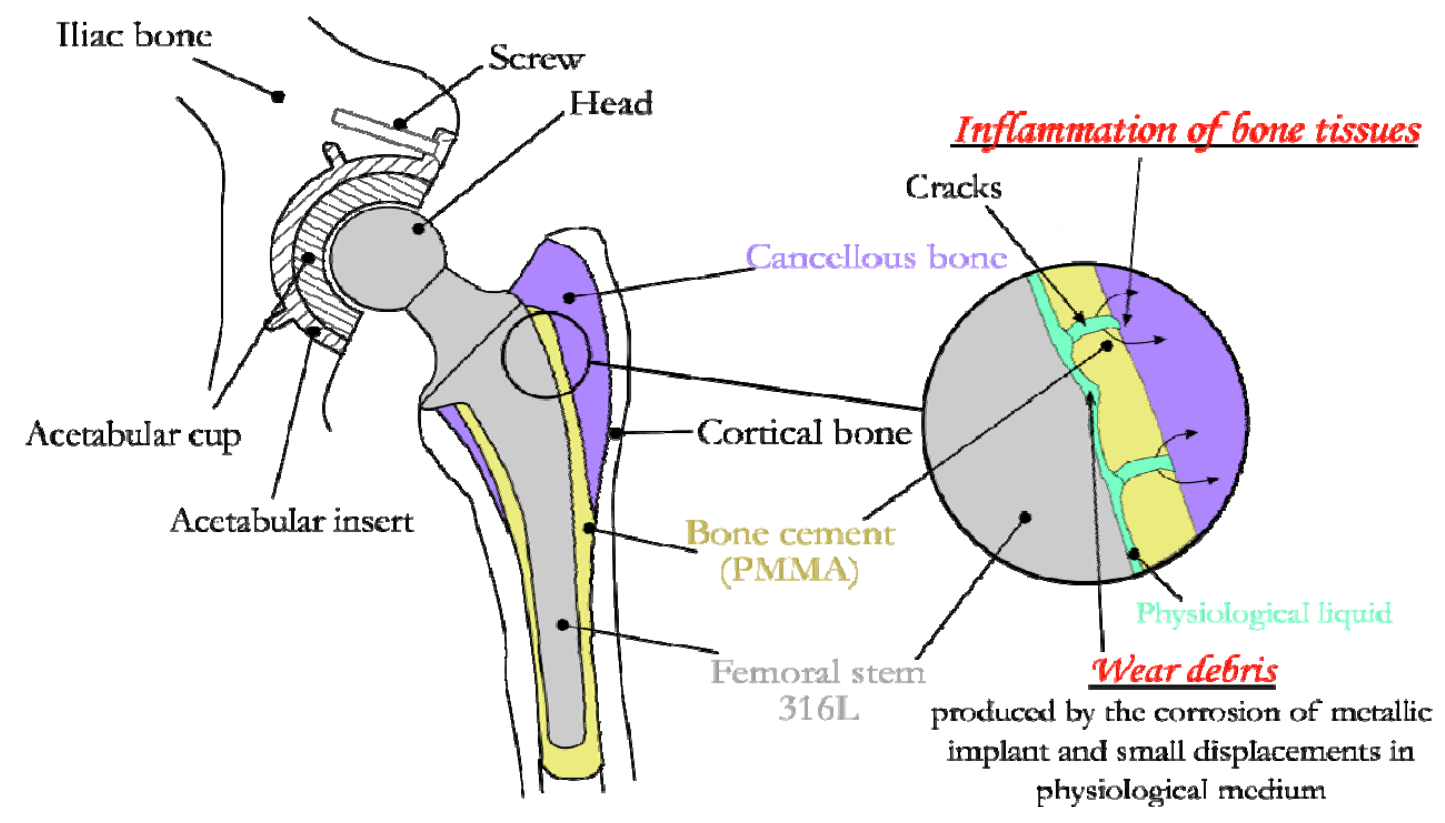

Figure 1: Total hip joint cemented prosthesis components 
The most noticeable parameter of cells and tissues response is debris size. In the case of $316 \mathrm{~L} \mathrm{SS}$, several ranges of debris sizes have been observed in vivo [9]: submicron particles and 1-5 $\mu \mathrm{m}$ irregular particles are frequent and 5-25 $\mu \mathrm{m}$ particles are rarely observed. Wilbert et al. found $77 \%$ of $316 \mathrm{~L} \mathrm{SS}$ particles less than $1.2 \mu \mathrm{m}, 17 \%$ were between 1.2 and $1.7 \mu \mathrm{m}$ and $6 \%$ were between 1.7 and $2.1 \mu \mathrm{m}$ [10].

In the case of PMMA debris, microscopic and submicroscopic particles are also observed in vivo. For cemented prostheses, PMMA is the most abundant material found in the surrounding tissues [6]. A wide range of sizes can be observed in recovered human tissues. The smallest particles are less than $1 \mu \mathrm{m}$ and even submicroscopic, probably inferior to $0.1 \mu \mathrm{m}$ [11]. Sharp particles from $1-5 \mu \mathrm{m}$ are commonly observed. Spherical particles from 5-25 $\mu \mathrm{m}, 20-200 \mu \mathrm{m}$ 'beads with pits and cracks' and 'irregular chunks' about $1 \mathrm{~mm}$ can also be observed [9].

Particles shape plays a role in tissues response. Small metal particles are 'globular' or 'irregularly shaped' and larger particles are 'sharp-edged' or 'spiked'. PMMA particles are commonly 'globular', 'spherical' or 'fragmented'. Globular particles are pre-polymerized ones and fragmented particles are the results of micro-displacements between the implant and bone cement or between the bone cement and bone [9].

The principal consequences of the presence of particles are the increase of contact surface between implant material and physiological fluid, particles phagocytosis and particles transport to lymph nodes, lungs or spleen [6]. Fretting-corrosion is one of the principal causes of debris generation and thus hip prosthesis loosening. That's why fretting-corrosion studies were carried out. In our case, the frettingcorrosion phenomenon between femoral stem and bone cement is modeled by fretting-corrosion between 316L SS sample and PMMA, which has same mechanical properties as bone cement.

Because of the complex composition (numerous salts and proteins) of physiological liquid, this work focuses on 1:1 solution, i.e. solution constituted only with $\mathrm{NaCl}$. The influence of ionic strength, I, defined by:

$$
I=\frac{1}{2} \sum_{i} z_{i}^{2} C_{i}
$$

where zi: ion charge and $\mathrm{Ci}$ : ion concentration, is then investigated.

In previous works $[12,13]$, several ionic strengths are studied: $\mathrm{NaCl}$ solution, with concentration of 10-3, 10-2, 10-1 and 1 mol.L-1, and also Ringer solution.

Some authors have shown the key- role of albumin $[14,15]$. Valero Vidal et al. show that albumin does not modify Open Circuit Potential (OCP) behavior but acts as an anodic inhibitor for 316L [15]. During a fretting-corrosion test between a Ti-6Al-4V alloy and alumina, Hiromoto et al. show that albumin does not affect the wear volume [16].

During a fretting-corrosion test, the total material loss, $\mathrm{W}$, is not only the sum of material loss due to mechanical wear obtained without the influence of corrosion, $\mathrm{W}_{\mathrm{m}}$, plus the material loss due to corrosion obtained without fretting action, $\mathrm{W}_{\mathrm{c}}$. There is a synergistic effect between corrosion and mechanical wear. The synergy term, $\Delta \mathrm{W}$, means that corrosion increases wear due to mechanics, $\Delta \mathrm{W}_{\mathrm{cm}}$, and mechanics increases wear due to corrosion, $\Delta \mathrm{W}_{\mathrm{mc}}[17,18]$. The relation between the total material loss and the different contributions of wear is thus given by:

$$
W=W_{m}+W_{c}+\Delta W=W_{m}+W_{c}+\left(\Delta W_{c m}+\Delta W_{m c}\right)
$$


Fretting-corrosion tests are investigated for two electrochemical conditions. To be as close as possible to the in vivo conditions, tests are investigated at OCP conditions. No information on corrosion current can be obtained in this electrochemical condition. That's why, fretting-corrosion tests are also investigated at applied potential, $\mathrm{E}=-400 \mathrm{mV}(\mathrm{SCE})$. This value is close to the OCP value during fretting and is a threshold potential for anodic and cathodic transitions of current $[12,13]$.

The aim of this work is to observe and determine the influence of ionic strength and albumin at cathodic applied potential $(\mathrm{E}=-400 \mathrm{mV}(\mathrm{SCE})$ ) on corrosion current, wear volume and synergy but also, thanks to Atomic Force Microscope (AFM) images, on the size, the shape and the quantity of debris. AFM lets us analyze nanometric particles and this typical size is the one which could involve significant problems on the biologic response of cells (inflammation or destruction of bone tissues). Micro-pitting corrosion of $316 \mathrm{~L}$ can also be observed.

\section{Materials and methods}

\subsection{Materials}

To model the contact between the femoral stem and the bone cement, a parallelepiped $(9 \mathrm{~mm} \mathrm{x}$ $9 \mathrm{~mm} \times 20 \mathrm{~mm}$ ) 316L SS sample and a cylindrical (length of $15 \mathrm{~mm}$ and radius of curvature of $10 \mathrm{~mm}$ ) PMMA sample are used. The composition of 316L SS is presented in Table 1.

One of the flat parts of the 316L SS sample was polished with diamond paste down to $1 \mu \mathrm{m}$. The $3 \mathrm{D}$ roughness parameters are measured with a Bruker Nanoscope ${ }^{\mathrm{TM}}$ Corp. (ex Veeco ${ }^{\mathrm{TM}}$ ) optical profilometer and calculated per the ANSI B46.1 standard: $\mathrm{S}_{\mathrm{a}} \sim 10 \pm 2 \mathrm{~nm}, \mathrm{~S}_{\mathrm{q}} \sim 7 \pm 0.1 \mathrm{~nm}, \mathrm{~S}_{\mathrm{z}} \sim$ $97 \pm 13 \mathrm{~nm}$ and $\mathrm{S}_{\mathrm{p}} \sim 44 \pm 11 \mathrm{~nm}$. To allow the formation of a stable surface film on the test samples, they were stored for about 24 hours in a desiccator.

PMMA is a polymer which has same mechanical properties than the ones of bone cement. The cylindrical face was polished with $3 \mu \mathrm{m}$ diamond solution, Altuglass Polish 1 and $2^{\circledR}$ and colloidal solution of silica (particles size of $0.06 \mu \mathrm{m}$ ). The $3 \mathrm{D}$ roughness, $\mathrm{S}_{\mathrm{a}}$, is about $35 \pm 5 \mathrm{~nm}, \mathrm{~S}_{\mathrm{q}} \sim$ $52 \pm 25 \mathrm{~nm}, \mathrm{~S}_{\mathrm{z}} \sim 2 \pm 1.6 \mu \mathrm{m}$ and $\mathrm{S}_{\mathrm{p}} \sim 0.9 \pm 0.7 \mu \mathrm{m}$.

\begin{tabular}{|c|c|c|c|c|c|c|c|c|c|c|}
\hline Elements & $\mathrm{Cr}$ & $\mathrm{Ni}$ & $\mathrm{Mo}$ & $\mathrm{Mn}$ & $\mathrm{Si}$ & $\mathrm{Co}$ & $\mathrm{C}$ & $\mathrm{Cu}$ & $\mathrm{S}$ & $\mathrm{Fe}$ \\
\hline Composition $(\% \mathrm{w} / \mathrm{w})$ & 17.4 & 13.0 & 2.6 & 1.73 & 0.66 & 0.20 & 0.0165 & 0.097 & $<0.001$ & Balance \\
\hline
\end{tabular}

Table 1: Chemical composition of 316L stainless steel, Z2CND17-12, in accordance with ISO standard 5832-1

\begin{tabular}{|c|c|c|c|c|}
\hline $\begin{array}{c}\text { Mechanical } \\
\text { properties }\end{array}$ & $\begin{array}{c}\text { Young's modulus E } \\
(\mathrm{GPa})^{*}\end{array}$ & $\begin{array}{c}\text { Poisson's } \\
\text { ratio * }\end{array}$ & $\begin{array}{c}\text { Yield stress } \\
(\mathrm{MPa})^{* *}\end{array}$ & $\begin{array}{c}\text { Ultimate tensile } \\
\text { strength (MPa)** }\end{array}$ \\
\hline 316L & 197 & 0.30 & 280 & 635 \\
\hline PMMA & 2.5 & 0.39 & 65 & 75 \\
\hline
\end{tabular}

Table 2: Mechanical properties of tested materials: 316L stainless steel and PMMA, *: obtained by ultrasonic measurements; **: manufacturer data

Mechanical properties of both materials are indicated in Table 2.

\subsection{Solutions}


Fretting-corrosion tests are investigated in $\mathrm{NaCl}$ solutions, with concentrations of $10^{-3}, 10^{-2}, 10^{-1}$ and 1 mol. $\mathrm{L}^{-1}$. AFM measurements focus principally on tests investigated in $\mathrm{NaCl} 10^{-3}$ and 1 mol. $\mathrm{L}^{-1}$. Room temperature was of $22 \pm 1{ }^{\circ} \mathrm{C}$. These solutions are used without or with a protein: albumin, 1 and 20 g.L $\mathrm{L}^{-1}$.

\subsection{Fretting-corrosion device}

Rubin et al. measured in vivo micro-displacements, about $50 \mu \mathrm{m}$ depending on the location, and stresses applied in vivo, between 7 and $30 \mathrm{MPa}$ [19]. In our study, the mechanical parameters for fretting-corrosion tests were:

- P, the applied normal load, $127.5 \mathrm{~N}$, which corresponds to a pressure of $22 \mathrm{MPa}$;

- , the amplitude of displacement, $\pm 40 \mu \mathrm{m}$. The displacement is sinusoidal with a frequency of $1 \mathrm{~Hz}$, i.e. the frequency of the gait cycle.

A new fretting-corrosion device (Figure 2) was conceived and developed in collaboration between ENSM-SE and Böse. For the first time, for fretting-corrosion tests, an electromagnetic motor was used. This new device lets us obtaining the same results that the ones delivered by the device used previously, using hydraulic motor [20,21]. A fretting-corrosion test lasts 4 hours, i.e. 14,400 cycles (1 second is 1 cycle).

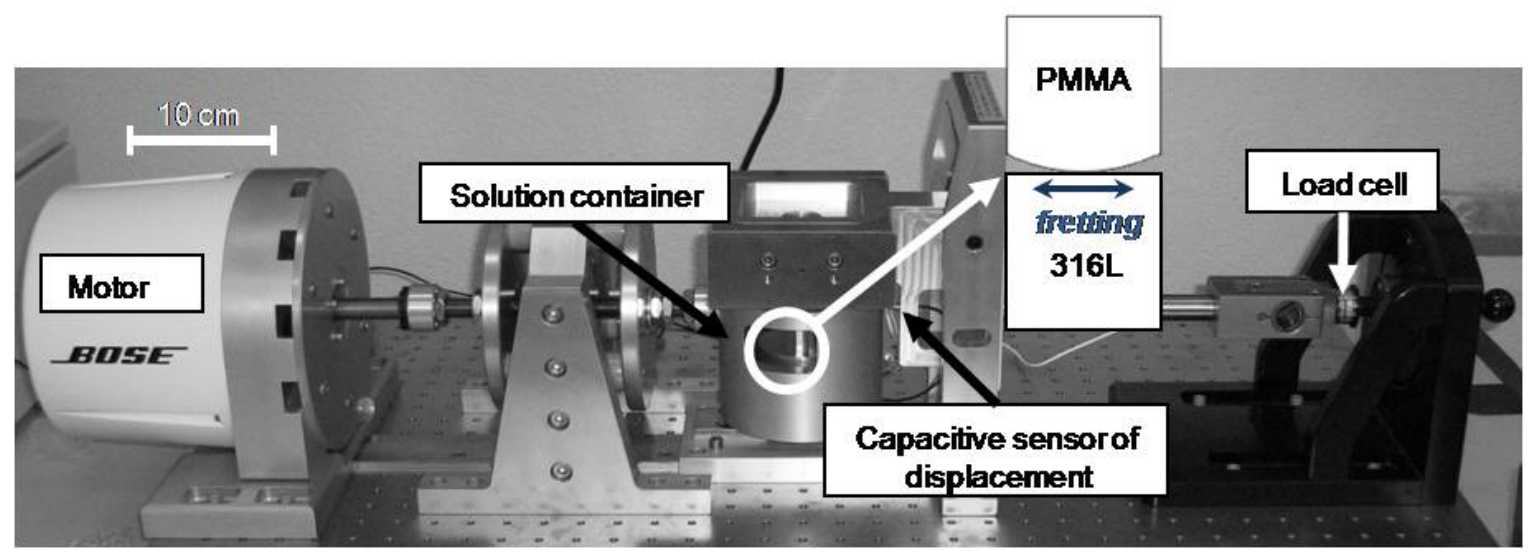

Figure 2: Fretting-corrosion device: ENSM-SE and Böse prototype

\subsection{Electrochemical measurements}

For OCP measurements and the applied cathodic potential, a PARSTAT 2263 potensiostat with a two-electrode for OCP and three-electrode for applied potential set up was used:

- the 316L SS was the working electrode,

- a circular Pt wire (diameter about $60 \mathrm{~mm}$ ) was the counter electrode,

- a Saturated Calomel Electrode (SCE, $\mathrm{E}=+246 \mathrm{mV}(\mathrm{SHE})$ at $\mathrm{T}=22^{\circ} \mathrm{C}$ ) was the reference electrode.

EIS measurements were also investigated to understand the behavior of the passive layer in presence of chlorides and albumin. They are explored from $10^{5} \mathrm{~Hz}$ to $10^{-1} \mathrm{~Hz}$ at a rate of 10 measurements frequencies/decade, with an AC amplitude of $10 \mathrm{mV}$. During friction tests, because of the non-stationarity conditions, EIS measurements should not be performed for actual values, but only the evolution of electrical parameters was considered [19]. 


\subsection{Surfaces analyses}

\subsubsection{Optical profilometer}

The total wear volume and the profile track of PMMA and 316L SS samples were carried out with Bruker Nanoscope $^{\mathrm{TM}}$ (ex. Veeco ${ }^{\mathrm{TM}}$ ) WYKO NT9100 optical profilometer. Measurements are carried out on three lengths of $2 \mathrm{~mm}$ and the total wear volume was thus extrapolated for the total wear track length $(15 \mathrm{~mm})$.

\subsubsection{Atomic Force Microscopy (AFM)}

The surface morphology and the debris were analyzed by using a D3100 AFM equipped with a Nanoscope 5 electronic from Bruker Nanoscope ${ }^{\mathrm{TM}}$ (ex. Veeco ${ }^{\mathrm{TM}}$ ) manufacturer. The images were recorded in ambient conditions $\left(25^{\circ} \mathrm{C}\right.$ and $30 \%$ relative humidity) and in soft intermittent contact mode (IC-AFM or Tapping ${ }^{\mathrm{TM}}$ AFM). Tap 150 tapping mode cantilever (Veeco model $\mathrm{n}^{\circ}$ MPP-12100) with a typical spring constant of about $5 \mathrm{~N} . \mathrm{m}^{-1}$ and a resonance frequency around $140 \mathrm{kHz}$ was used for scanning. Tapping force was controlled by the ratio between setpoint amplitude $\left(\mathrm{A}_{\mathrm{sp}}\right)$ and the free air amplitude $\left(\mathrm{A}_{0}\right)$. The scan rate was adjusted in the range of $0.4-0.5 \mathrm{~Hz}$ depending on the image quality. Each scan line contains 512 pixels and a whole image is composed of 512 scan lines. For acquisition of surface morphology, amplitude error and height images were recorded on several areas of film surface. AFM images are made in the wear track: at the center of the wear track and in the "hollow of the W wear track"; and at 50,200,500 and $1500 \mu \mathrm{m}$ from the edge of the wear track. The scan angle is perpendicular to wear track.

All offline image flattening and analyses of the images were conducted at the software environment provided by the AFM manufacturer (version 7.3). The statistical parameters related with sample roughness [22] were estimated by the software equipment: average roughness $\left(\mathrm{R}_{\mathrm{a}}\right)$ and root mean square roughness $\left(\mathrm{R}_{\mathrm{q}}\right)$ were only presented. The particles and pits analyze is performed with SPIPTM, by Image Metrology A/S and WSxM v3.0 [23].

For example, AFM images are carried out for a polished 316L SS surface (Figure 3). The average of surface roughness, $R_{a}(3$ measurements of $30 \times 30 \mu \mathrm{m})$, is: $R_{a}=2.6 \pm 0.2 \mathrm{~nm}$. Some grooves and particles can be observed. They came from polishing step. One may notice that roughness values are not the same for AFM or optical profilometer $\left(S_{a}=10 \pm 2 \mathrm{~nm}\right)$. One might suggest this difference is due to the different size of surfaces and the methods of measurements, i.e. optical profilometer or AFM measurements. 


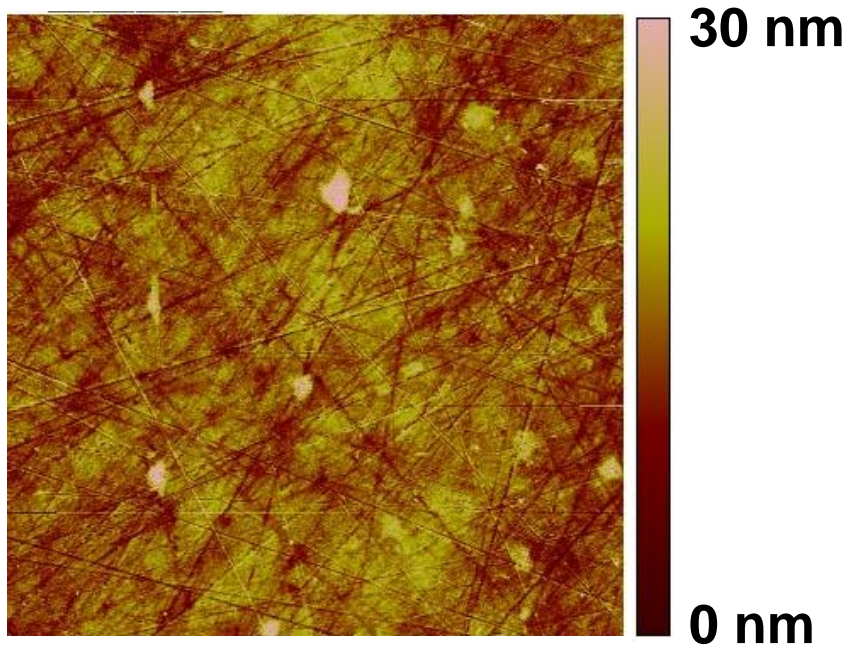

Figure 3: 316L SS polished surface, AFM measurement in height mode, $30 \mu \mathrm{m} \times 30 \mu \mathrm{m}$

\section{Results and discussion}

\subsection{The role of albumin and chlorides on 316L without fretting}

Linear sweep voltammetry is investigated in order to stabilize the electrochemical role of albumin on 316L SS. These polarizations are made in $\mathrm{NaCl} 1$ and $10^{-3} \mathrm{~mol} \cdot \mathrm{L}^{-1}$, without albumin and with an albumin concentration of $20 \mathrm{~g} . \mathrm{L}^{-1}$. The potential range is from $-1 \mathrm{~V}(\mathrm{SCE})$ to $0.4 \mathrm{~V}(\mathrm{SCE})$, at a rate of $1.5 \mathrm{mV} \cdot \mathrm{min}^{-1}$. As shown on Figure 4, albumin shifts the corrosion potential to higher values. It promotes the protection of the 316L SS surface. Moreover the anodic current, experiments with albumin, decreases with the increasing of protein. Karimi et al. [24] show the potentiodynamic polarization behavior of 316L SS in a Phosphate Buffered Solution (PBS), with different Bovine Serum Albumin (BSA), concentrations at $37{ }^{\circ} \mathrm{C}$ in aerated conditions. They show that the cathodic polarization branch shifted to a lower potential value when BSA concentration increases and that albumin plays a significant role on anodic branch. The passive film formation became more stable in presence of BSA. In PBS, interactions between albumin, ions and passive layer lead to a stabilization of the passive layer. Finally the highest concentration of $1 \mathrm{~mol} . \mathrm{L}^{-1}$ promotes the corrosion as expected.

To conclude albumin acts as an anodic inhibitor for $316 \mathrm{~L} \mathrm{SS}$, it prevents from the corrosion. This preliminary study is the base of the following studies under fretting corrosion. 


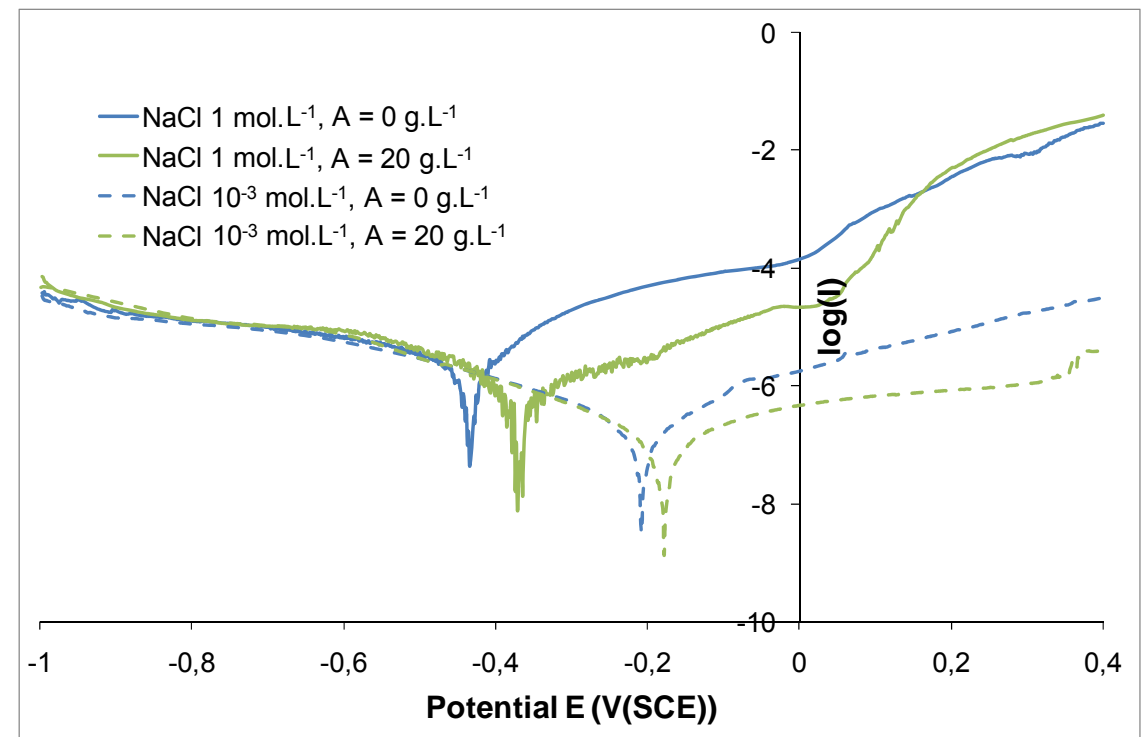

Figure 4: Linear polarization, without fretting, in $\mathrm{NaCl} 1$ mol.L $\mathrm{L}^{-1}$ (solid lines) and $\mathrm{NaCl} 10^{-3}$ mol.L $\mathrm{L}^{-1}$ (dashed lines), without albumin (blue) and with a concentration of $20 \mathrm{~g} . \mathrm{L}^{-1}$ in albumin (green)

\subsection{The role of albumin and chlorides on 316L during fretting-corrosion investigations}

\subsubsection{OCP measurements}

Two electrochemical conditions were investigated for this study. First, the Open Circuit Potential (OCP) condition allows being as close as possible to the in vivo conditions. However, no information on current, and thus on synergy terms, is available. Thus, fretting-corrosion tests are also carried out at cathodic applied potential. The average value of OCP during fretting, $\mathrm{E}_{\mathrm{mf}}$ decreases with ionic strength and $\mathrm{E}_{\mathrm{mf}}=-400 \pm 50 \mathrm{mV}(\mathrm{SCE})$ [13]. That's why the chosen applied potential will be $\mathrm{E}=-$ $400 \mathrm{mV}(\mathrm{SCE})$. Anyway, we will focus our attention on OCP investigations.

A specific procedure was investigated about the electrochemical conditions. After a polarization at $-1 \mathrm{~V}(\mathrm{SCE})$ to obtain a homogeneous passive layer, the OCP or current is measured $1 \mathrm{~h}$ and $10 \mathrm{~min}$ respectively before fretting, during the fretting (4 hours) and $40 \mathrm{~min}$ after fretting stops. At regular intervals (every 20 minutes), the polarization resistance $\left(R_{p}\right)$ is determined with Electrochemical Impedance Spectroscopy (EIS) in order to investigate the behavior of the metal surface. $\mathrm{R}_{\mathrm{p}}$ was extracted from the simple electrical circuit: $R_{\text {sol }}\left(C P E / / R_{p}\right), R_{\text {sol }}$ is the solution resistance, CPE is a Constant Phase Element and $R_{p}$ is the polarization resistance, resistance of the passive layer and the double layer at high frequencies.

The influence of albumin is not seen on the average OCP during fretting. It seems that OCP is not a relevant value to understand the role of albumin [15]. However, as shown on Figure 5, the role of chlorides and of albumin can be highlighted thanks to the average $\mathrm{R}_{\mathrm{p}}$ value during fretting.

The passive layer is less protective when the ionic strength increases (Figure 5): the raise of chlorides concentration facilitates the metallic dissolution. Besides, the presence of albumin increases the polarization resistance: albumin tends to protect the 316L surface against corrosion. The key point is also that the polarization resistance is a more relevant value than OCP for understanding the role of albumin on $316 \mathrm{~L}$ behavior.

As shown without fretting $(\S 3.1)$, albumin acts as a corrosion inhibitor, even during frettingcorrosion tests. 


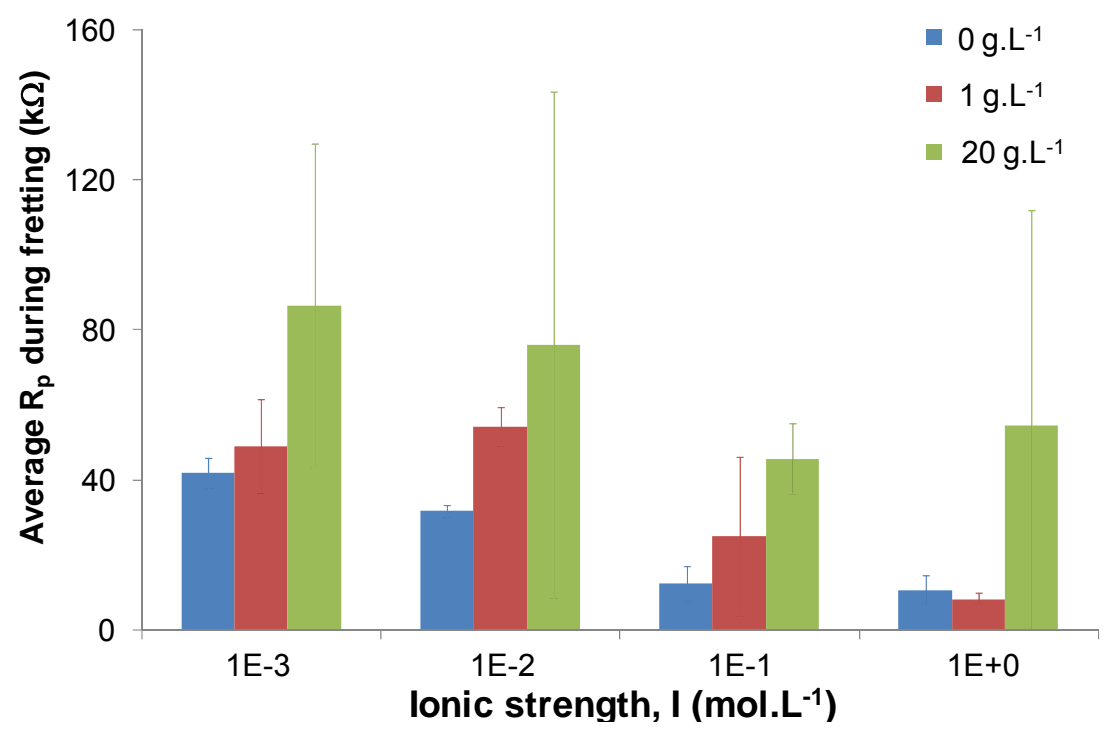

Figure 5: Average polarization resistance $\left(R_{p}\right)$ during fretting as function of ionic strength and albumin concentration

\subsubsection{Cathodic applied potential}

Investigations at cathodic applied potential $(\mathrm{E}=-400 \mathrm{mV}(\mathrm{SCE}))$ give information on the role of albumin and on the synergy between corrosive and mechanical wear. As seen on Figure 6, the evolution of current as a function of time varies with the concentration of albumin.

Without albumin, the current increases during fretting and even becomes positive, i.e. anodic: fretting induces an additional metal dissolution. Besides, at the end of fretting, the difference between the current at the end of fretting and the current after fretting $(\Delta \mathrm{I})$ confirms the corrosion induced by fretting. As a conclusion, for $\mathrm{NaCl} 1 \mathrm{~mol}^{-1} \mathrm{~L}^{-1}$ (Figure 6), $\Delta \mathrm{I}$ and the current during fretting decrease when the albumin concentration increases.

The fretting allows destroying the passive layer for promoting the dissolution of metals, corroborating by the measured positive current during fretting experiments. The albumin protects from the dissolution during fretting corrosion experiments. 


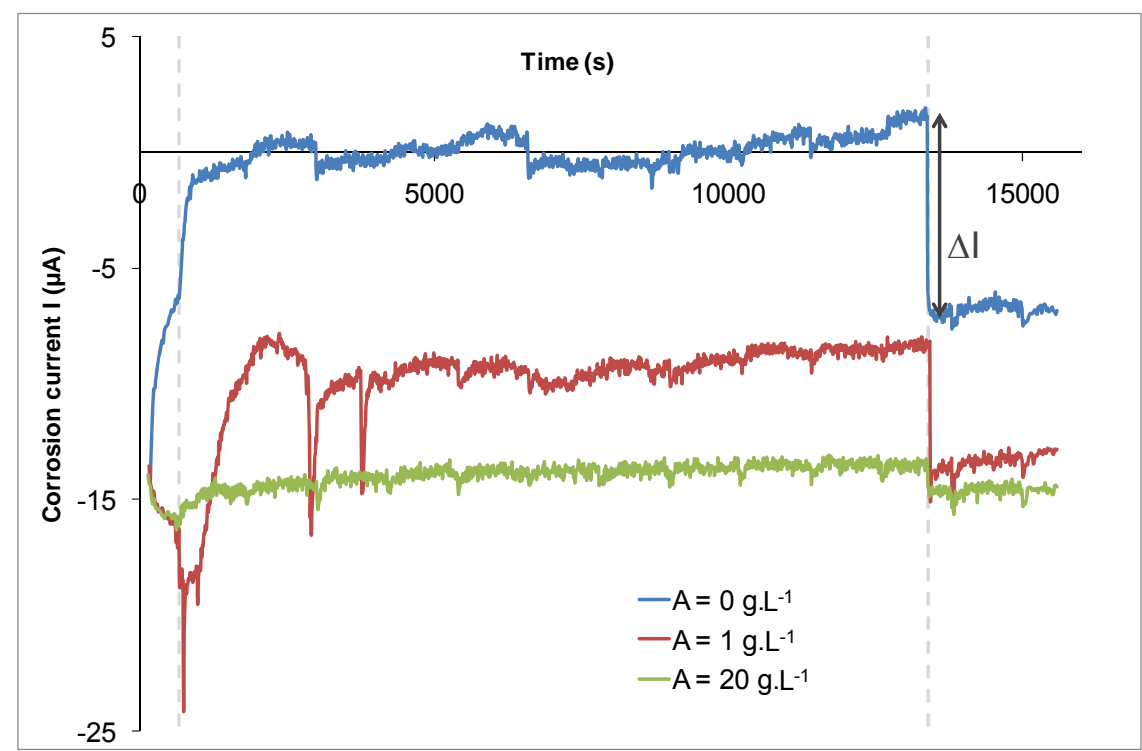

Figure 6: Evolution of corrosion current as a function of time in solution of $\mathrm{NaCl} 1 \mathrm{~mol}^{-\mathrm{L}^{-1}}$ without albumin (blue), with 1 g.L $\mathrm{L}^{-1}$ (red) and 20 g.L $\mathrm{L}^{-1}$ (green)

$\Delta \mathrm{I}$ is a function of albumin concentration and also of ionic strength (Figure 7). $\Delta \mathrm{I}$ increases with ionic strength, without albumin and for a concentration in albumin of 1 g. $\mathrm{L}^{-1}$.

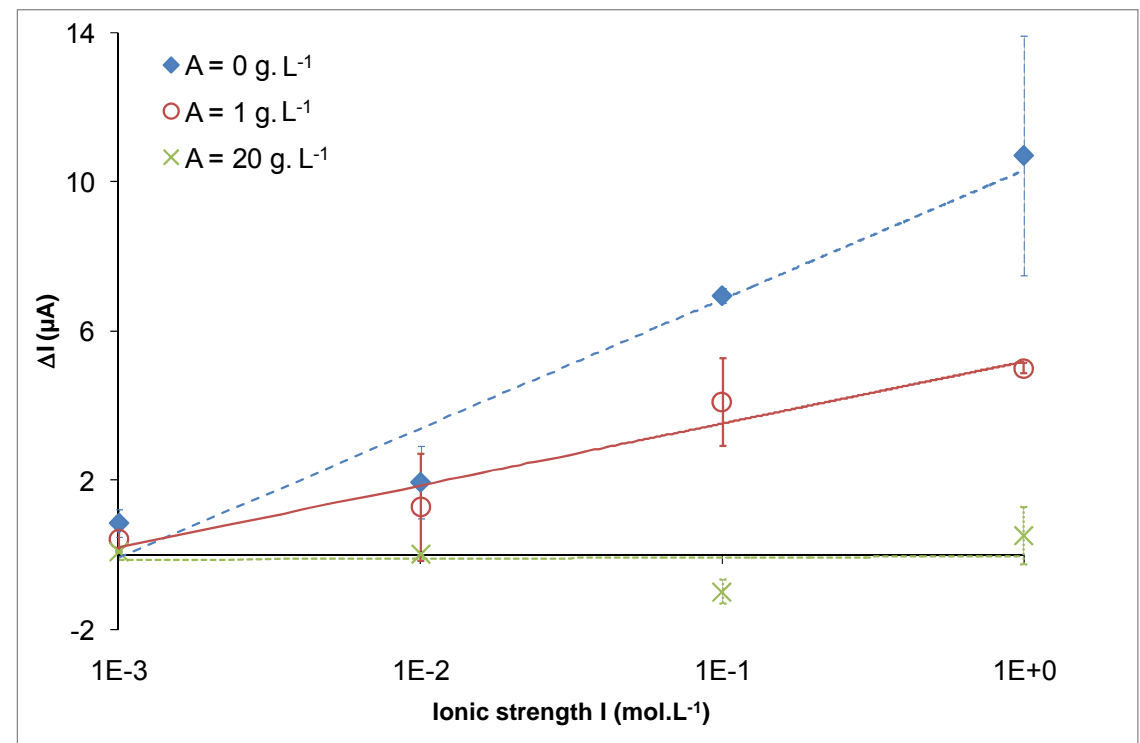

Figure 7: Difference between current at the end of fretting and after fretting, I versus ionic strength I for tests without albumin $(\diamond)$, with 1 g.L $\mathrm{L}^{-1}(\bullet)$ and 20 g.L $\mathrm{L}^{-1}(X)$

The applied potential, $\mathrm{E}=-400 \mathrm{mV}(\mathrm{SCE})$, is cathodic and thus the surface is protected against corrosion without fretting. However, for concentrations of $10^{-1}$ and 1 mol. $\mathrm{L}^{-1}, \quad \mathrm{I}$ is superior to $5 \mu \mathrm{A}$. The applied potential turns out to be too high and does not protect the surface anymore during fretting. For concentrations of $10^{-3}$ and $10^{-2}$ mol. $\mathrm{L}^{-1}, \Delta \mathrm{I}$ is very low, between 1 and $2 \mu \mathrm{A}$. In both cases, the applied potential protects the surface during fretting and the metal dissolution is the weakest. The concentration in albumin of $1 \mathrm{~g} . \mathrm{L}^{-1}$ slightly decreases $\Delta \mathrm{I}$ for $10^{-1}$ and $1 \mathrm{~mol} . \mathrm{L}^{-1}$. For a concentration of 
albumin equal to $20 \mathrm{~g} . \mathrm{L}^{-1}, \quad \mathrm{I}$ is constant as a function of ionic strength. This concentration decreases and even deletes the additional metal dissolution due to fretting for all the ionic strength. Albumin acts as a corrosion inhibitor and it prevents from the anodic dissolution of 316L SS. As expected in the part 3.1, albumin could have the role of an anodic inhibitor during fretting corrosion.

As illustrated on Figure 8, for 316L SS samples, total material loss increases with ionic strength for both electrochemical conditions. A threshold concentration, $\mathrm{C}_{\ell}$, is then highlighted. $\mathrm{C}_{\ell}$ is about $10^{-1}$ mol.L $\mathrm{L}^{-1}$ without albumin and about 1 mol. $\mathrm{L}^{-1}$ for a concentration of $20 \mathrm{~g} . \mathrm{L}^{-1}$. These threshold concentrations highlight the transition between the surface protection at applied potential, i.e. the concentration is inferior to $\mathrm{C}_{\ell}$, and the additional metallic dissolution, i.e. the concentration is inferior to $C_{\ell}$. In presence of albumin, $C_{\ell}$ increases: albumin decreases metal degradation and seems to have a protective effect against corrosion.

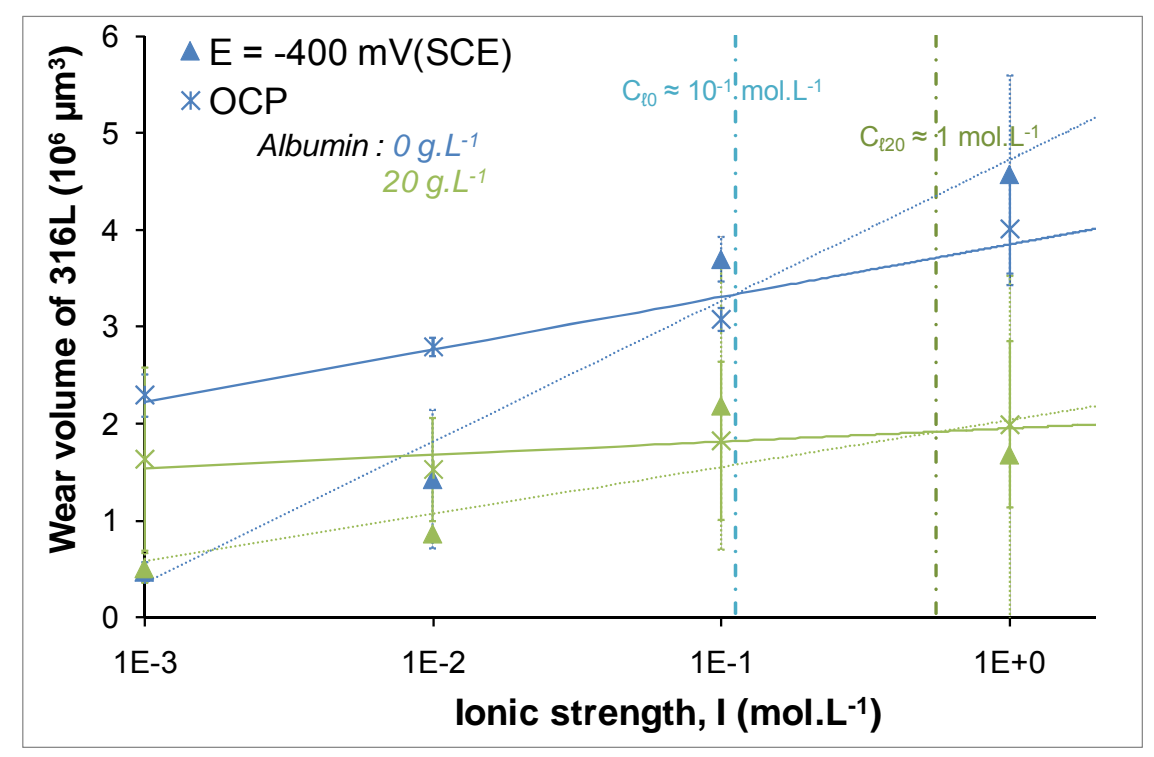

Figure 8: Wear volume of 316 $\mathrm{L}$ as a function of ionic strength for albumin concentrations of 0 g. $\mathrm{L}^{-1}$ (blue) and 20 g.L $\mathrm{L}^{-1}$ (green) at cathodic applied potential $(\Delta)$ and OCP (*)

\subsubsection{Synergy between corrosive and mechanical wear}

The total wear volume of 316L SS is measured from optical profilometer. The total wear volume is a function of ionic strength (Figure 9): 316L SS degradation is higher for high concentration of chloride ions. Besides, albumin tends to decrease the wear volume of $316 \mathrm{~L}$ SS. As shown with equation (2), the wear volume of $316 \mathrm{~L}$ SS is a combination of corrosion and mechanical wear. Albumin and chlorides must have different effect on synergy terms.

To obtain the wear volume only due to mechanical wear, $\mathrm{W}_{\mathrm{m}}$, fretting-corrosion tests are made at $\mathrm{E}$ $=-800 \mathrm{mV}(\mathrm{SCE})$. In this way, anodic dissolution, i.e. metallic dissolution, is neglected whatever ionic strength or the presence or not of albumin. The mechanical wear $\mathrm{W}_{\mathrm{m}}$ is also determined: $\mathrm{W}_{\mathrm{m}}=$ $0.3 \pm 0.110^{6} \mu \mathrm{m}^{3}$.

At $\mathrm{E}=-400 \mathrm{mV}(\mathrm{SCE})$, the wear volume due to corrosion, $\mathrm{V}_{\text {corr }}$, is calculated thanks to the Faraday's law [25]:

$$
V_{\text {corr }}=\frac{1}{F} * \frac{M}{n \rho} * i * t
$$


where $F$ is the Faraday constant $\left(F=96500 \mathrm{C} \cdot \mathrm{mol}^{-1}\right), M$ is the molecular weight $\left(M=56.39 \mathrm{~g} \cdot \mathrm{mol}^{-1}\right), n$ the number of electrons involved in the anodic process $(n=2$, hypothesis $), t$ the total duration of the fretting-corrosion test $(t=14,400 \mathrm{~s}), \rho$ the density $\left(\rho=8 \mathrm{~g} \cdot \mathrm{cm}^{-3}\right)$ and $i$ the difference between the average current during fretting and the current after fretting.

In fact, $\mathrm{V}_{\text {corr }}=\mathrm{W}_{\mathrm{c}}+\Delta \mathrm{W}_{\mathrm{mc}}$. To set apart the synergy term $\Delta \mathrm{W}_{\mathrm{mc}}$, the term $\mathrm{W}_{\mathrm{c}}$ must be measured. From polarization resistance values, the dissolution current of the material, $i$, can be calculated: $i=$ $\mathrm{B} / \mathrm{R}_{\mathrm{p}}$, with $\mathrm{B}=24 \mathrm{mV}$ (hypothesis coming from investigations in the COST 533 round robin). In that way, $\mathrm{W}_{\mathrm{c}} \sim 100$ or $500 \mu \mathrm{m}^{3}$ depending on the ionic strength. $\mathrm{W}_{\mathrm{c}}$ represented only $0.01 \%$ of $\mathrm{V}_{\text {corr }}$ and thus can be neglected. Iwabuchi et al. found the same ratio $[12,26]$. Then, the term $\Delta \mathrm{W}_{\mathrm{cm}}$ can be deducted from equation (2).

The major influence of chlorides and albumin can be seen on the wear-induced corrosion term $\left(\Delta \mathrm{W}_{\mathrm{mc}}\right): \Delta \mathrm{W}_{\mathrm{mc}}$ increases with the ionic strength and decreases with the albumin concentration (Figure 9).

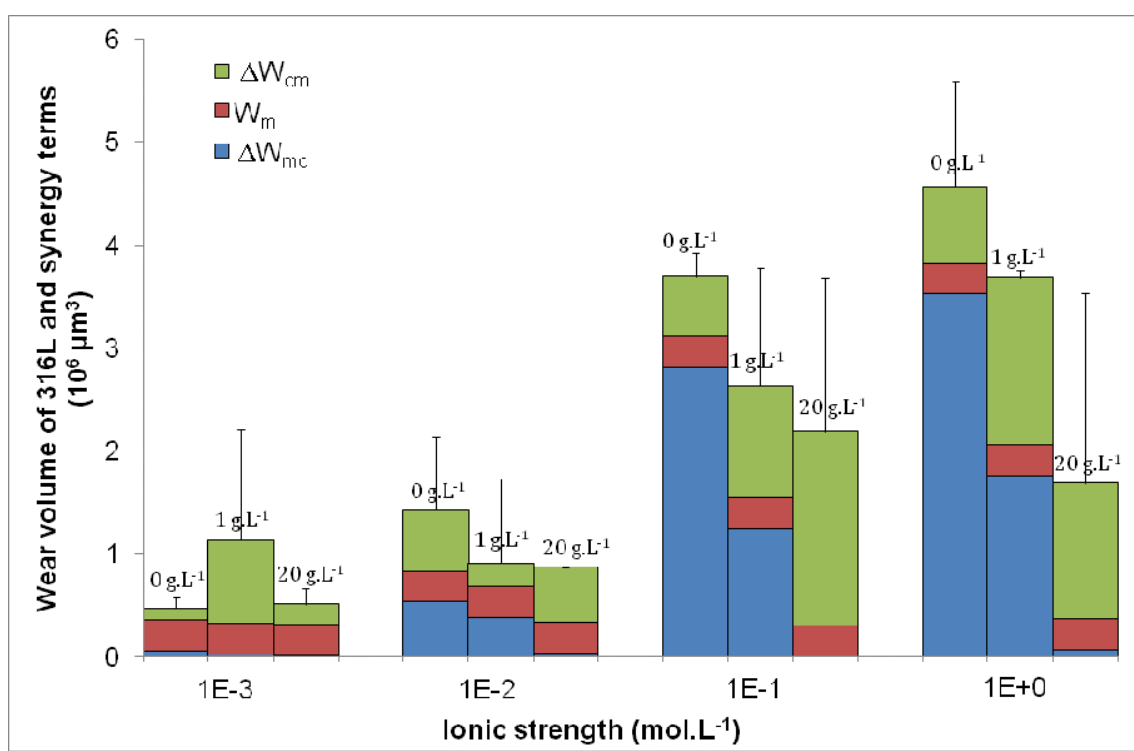

Figure 9: Total wear volume of 316L SS and the different terms of equation (2) as a function of ionic strength, without albumin, and with 1 and 20 g. $\mathrm{L}^{-1}$ of albumin

\subsection{Wear track area, optical profilometry and AFM investigations}

\subsubsection{Chloride ions influence}

Chloride ions, $\mathrm{Cl}^{-}$, accelerate anodic dissolution with the formation of an unstable compound $\mathrm{MCl}_{\mathrm{n}}$ (or $\left.\mathrm{M}\left(\mathrm{H}_{2} \mathrm{O}\right)_{\mathrm{y}} \mathrm{Cl}_{\mathrm{x}}\right)$ [27]. At high concentration of chloride ions, one may suggest that metallic dissolution is higher, and leads to a higher wear volume and a higher corrosive wear volume. Hong et al. show that at applied potential, the corrosive wear rates increased linearly with increasing chloride ion concentration, without albumin [28].

Thanks to AFM measurements, the number of pits and their size can be investigated with SPIPTM software by Image Metrology A/S. According to Malik et al. [29]: "the number and depth of pits increase with increasing $\mathrm{Cl}^{-}$concentration". In our case, without albumin, the same tendency is observed. For the whole analyzed surfaces, at OCP, the number of pits per surface unit goes from 0.003 pits $/ \mu \mathrm{m}^{2}$ in $\mathrm{NaCl} 10^{-3} \mathrm{~mol} . \mathrm{L}^{-1}$ to $0.013 \mathrm{pits} / \mu \mathrm{m}^{2}$ in $\mathrm{NaCl} 1 \mathrm{~mol} . \mathrm{L}^{-1}$, and at applied potential, the number goes from 0.03 pits $/ \mu \mathrm{m}^{2}$ in $\mathrm{NaCl} 10^{-3} \mathrm{~mol} . \mathrm{L}^{-1}$ to $0.05 \mathrm{pits} / \mu \mathrm{m}^{2}$ in $\mathrm{NaCl} 1 \mathrm{~mol} . \mathrm{L}^{-1}$. The depth of 
pits is about $15 \pm 5 \mathrm{~nm}$ and they are slightly deeper for $\mathrm{NaCl} 1 \mathrm{~mol} . \mathrm{L}^{-1}$, but no valid tendency can be proved due to small analyzed area. Further investigations will be carried out for determining statistically the number of pits according to the $\mathrm{NaCl}$ concentration.

On Figure 8, we have seen that at $10^{-3} \mathrm{~mol}^{-\mathrm{L}^{-1}}$, the $316 \mathrm{~L}$ SS surface is protected at $\mathrm{E}=$ $400 \mathrm{mV}(\mathrm{SCE})$ compared to OCP condition, and at $1 \mathrm{mol. \textrm {L } ^ { - 1 }}$, the metallic dissolution is more important at $\mathrm{E}=-400 \mathrm{mV}(\mathrm{SCE})$ than at $\mathrm{OCP}$. The cathodic potential $\mathrm{E}=-400 \mathrm{mV}(\mathrm{SCE})$ is a protective one during the fretting-corrosion test for $\mathrm{NaCl} 10^{-3} \mathrm{~mol} . \mathrm{L}^{-1}$ but not for $1 \mathrm{~mol} . \mathrm{L}^{-1}$. On Figure $10 \mathrm{a}$, only grooves are observed in the wear track. In $\mathrm{NaCl} 10^{-3} \mathrm{~mol} \cdot \mathrm{L}^{-1}$ and at $\mathrm{E}=-400 \mathrm{mV}$ (SCE), corrosive wear is negligible (cf. Figure 9). Thus, the total wear volume corresponds to the mechanical wear. This wear profile corresponds, as a consequence, to mechanical wear. At OCP, there is no protection against corrosion: the wear track has some irregular grooves corresponding to a weak corrosive wear (Figure $10 \mathrm{c}$ ). On the other hand, on Figure $10 \mathrm{~b}$, for $\mathrm{NaCl}$ solution of 1 mol.L ${ }^{-1}$, the structure of the wear track corresponds to irregular wear with no grooves and thus to corrosive wear. At OCP (Figure $10 \mathrm{~d}$ ), there is less corrosion than at applied potential (Figure 8): the structure of the wear track corresponds to mechanical grooves and some corrosion sites.
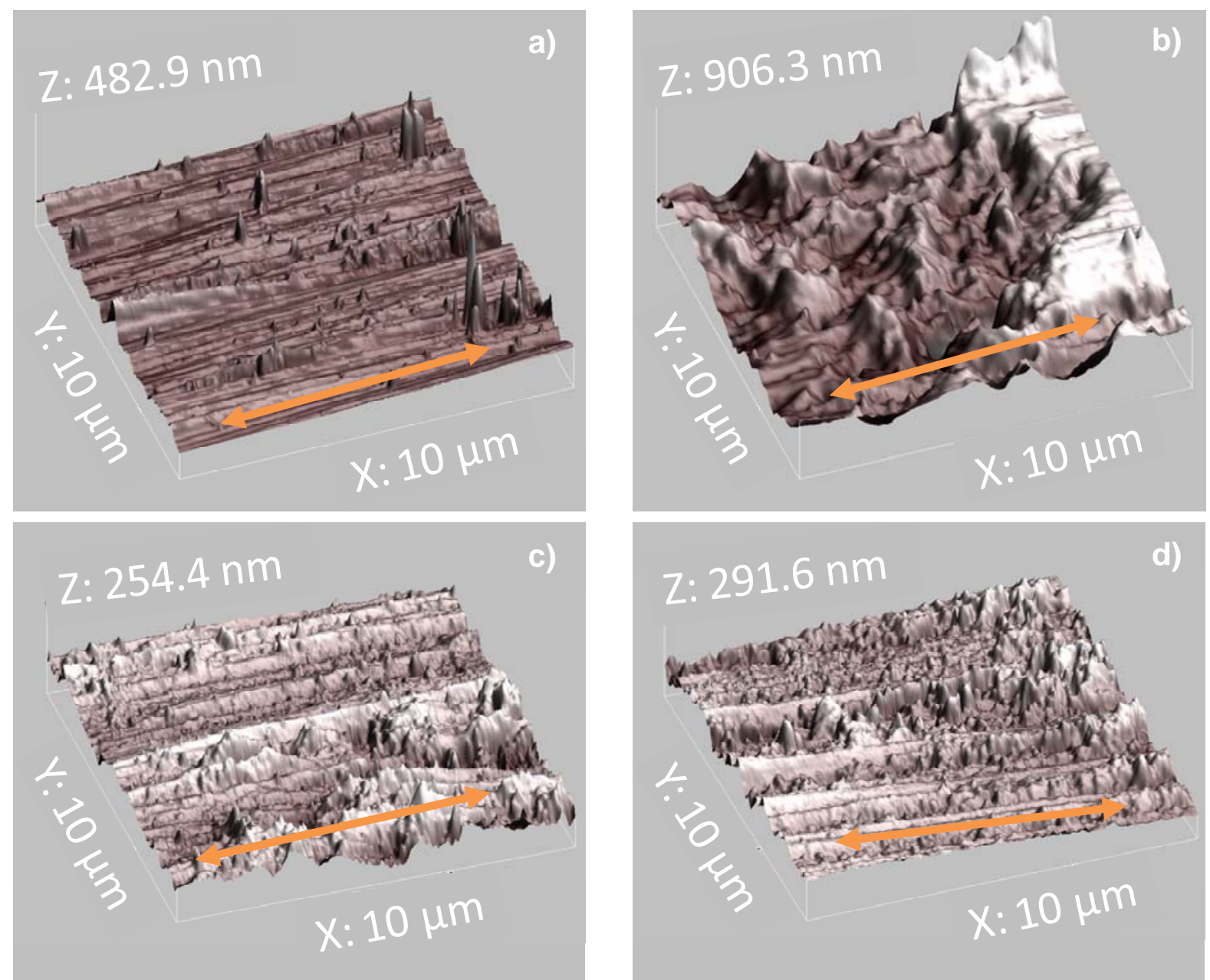

Figure 10: 3D AFM images $(10 \times 10 \mu \mathrm{m})$ in the "hollow of the W wear track" without albumin, a) for $\mathrm{NaCl}$ solution of $10^{-3} \mathrm{~mol}^{-\mathrm{L}^{-1}}$ and at $\mathrm{E}=-\mathbf{4 0 0} \mathrm{mV}(\mathrm{SCE})$, b) for $\mathrm{NaCl}$ solution of 1 mol. $\mathrm{L}^{-1}$ and at $\mathrm{E}=-400 \mathrm{mV}(\mathrm{SCE})$, c) for $\mathrm{NaCl}$ solution of $10^{-3} \mathrm{~mol} . \mathrm{L}^{-1}$ and at $\mathrm{OCP}$, d) for $\mathrm{NaCl}$ solution of 1 mol.L $\mathrm{L}^{-1}$ and at $\mathrm{OCP}$, arrows show direction of sliding 


\subsubsection{Albumin influence}

As shown on Figure 4, albumin acts as an anodic inhibitor without fretting and seems to have a similar role during fretting-corrosion test (Figure 9): the increase of albumin concentration leads to a significantly decrease of corrosive wear. For an albumin concentration of 20 g. $\mathrm{L}^{-1}, \Delta \mathrm{W}_{\mathrm{mc}}$ is inferior to $0.110^{6} \mu^{3}$ whatever the ionic strength (Figure 9).

AFM observations in the wear track seem to confirm the protective effect of albumin (Figure $\mathrm{i}$ and Figure _ii). Two phenomena are observed. For $\mathrm{NaCl} 10^{-3} \mathrm{~mol}^{-\mathrm{L}^{-1}}$ and for the two electrochemical conditions (Figure _ i b) and 11_ii b), formed plates are probably albumin. They recover the wear track area by adhesion mechanisms. The thickness of these plates is about $0.1 \mu \mathrm{m}$ at $\mathrm{OCP}$ and $0.5 \mu \mathrm{m}$ at $\mathrm{E}=$ $-400 \mathrm{mV}(\mathrm{SCE})$. One may suggest that albumin settles into the wear track and creates a thin protective layer against corrosion. A thicker layer is deposited at applied potential. For $\mathrm{NaCl} 1 \mathrm{~mol}^{-1} \mathrm{~L}^{-1}$ (Figure ii d), agglomeration of particles is observed into the wear track in presence of albumin. These particles may also protect against corrosion. They could be constituted by a mixing of PMMA debris and albumin. At applied potential, particles are bigger. The potential changes the charges distribution at the 316L SS surface and albumin behavior is thus modified [30]. The surface potential could be a point for explaining the different adsorption of proteins and PMMA debris on 316L SS.

Without albumin and for both electrochemical conditions and for $\mathrm{NaCl} 10^{-3} \mathrm{~mol} . \mathrm{L}^{-1}$ (Figure a and c), only grooves due to mechanical wear are observed. The small white particles are debris from PMMA or corrosion products. They are smaller than the ones from images obtained with albumin.
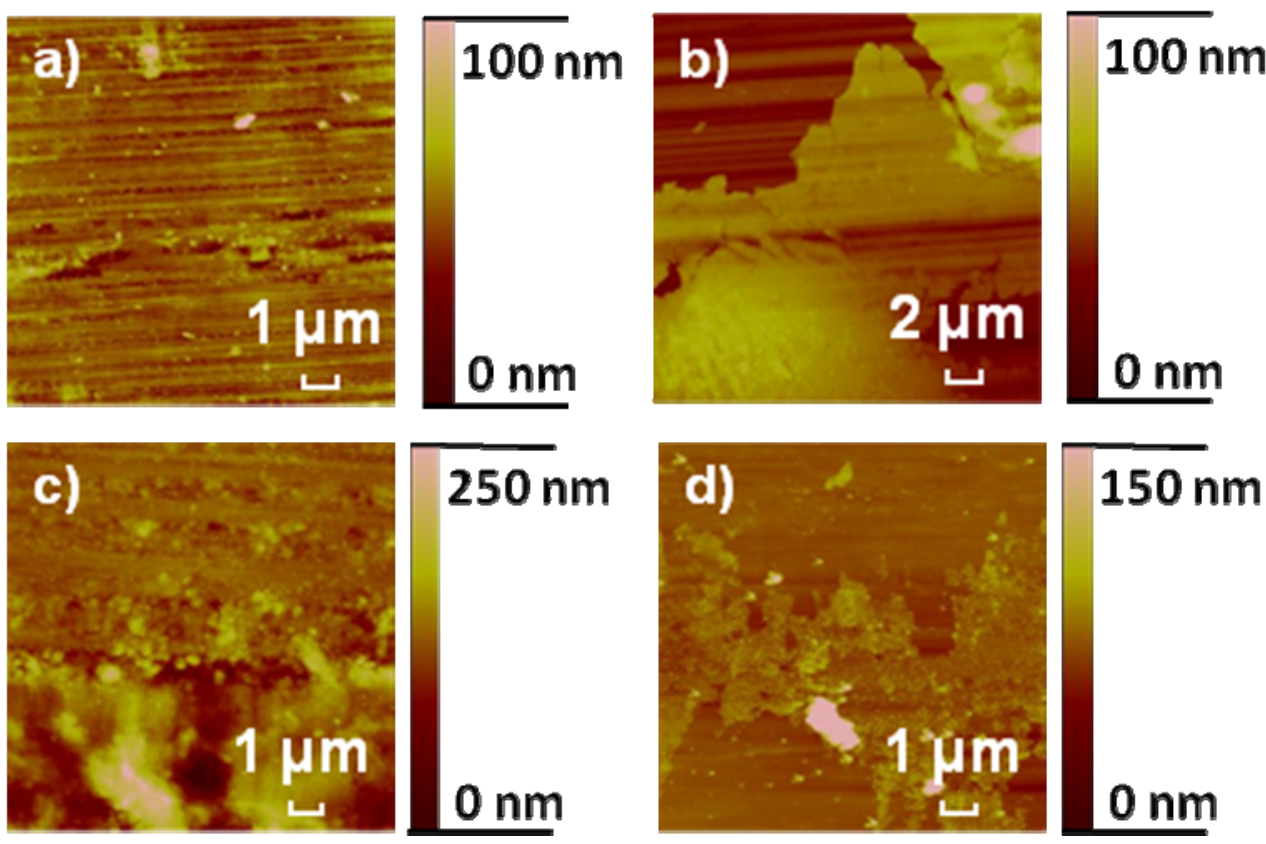

Figure 11_i: AFM images in height mode at the center of the wear track, at $\mathrm{OCP}$ for a) $\mathrm{NaCl}$ $10^{-3}$ mol.L ${ }^{-1}$, albumin 0 g. $\mathrm{L}^{-1}$; b) $\mathrm{NaCl} 10^{-3} \mathrm{~mol}^{-\mathrm{L}^{-1}}$, albumin 20 g.L $\mathrm{L}^{-1}$; c) $\mathrm{NaCl} 1$ mol.L $\mathrm{L}^{-1}$, albumin 0 g.L ${ }^{-1}$; d) NaCl 1 mol.L ${ }^{-1}$, albumin 20 g.L ${ }^{-1}$ 

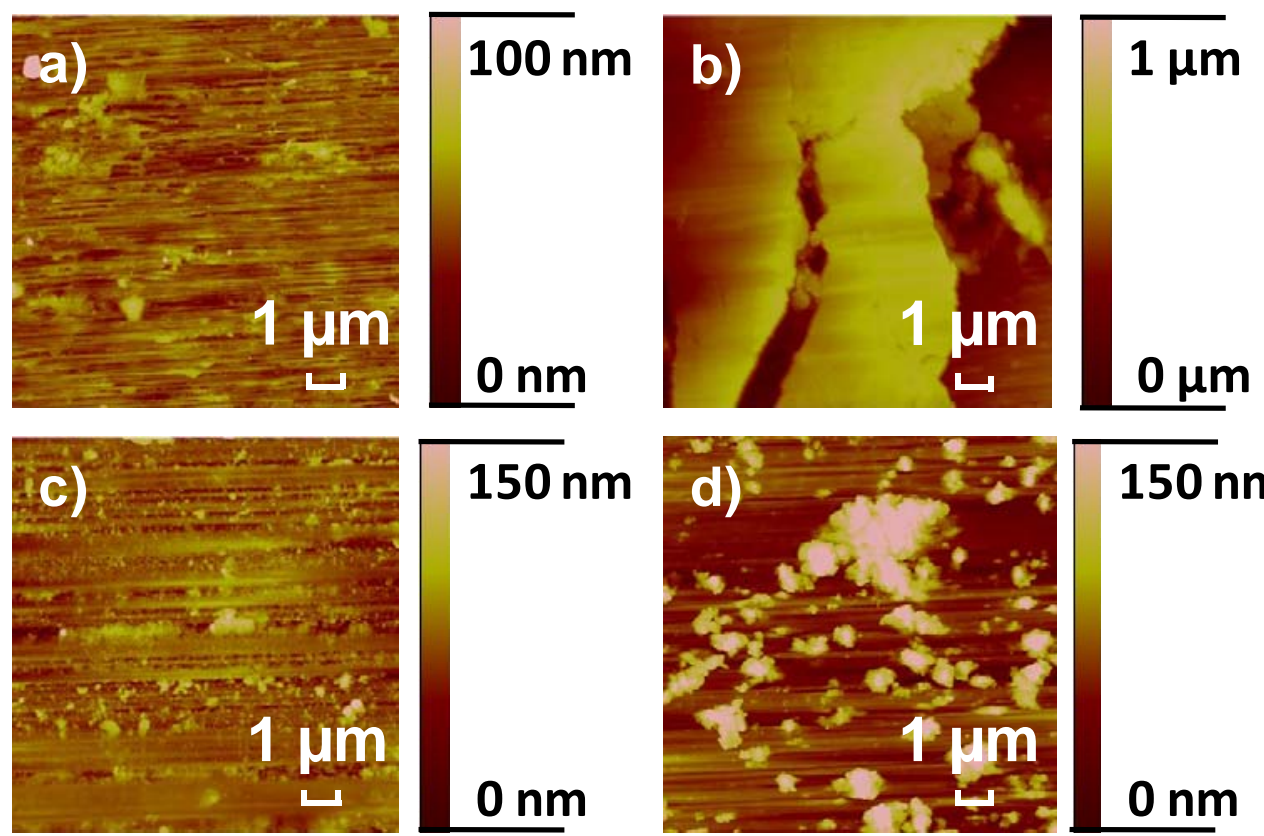

Figure 11_ii: AFM images in height mode at the center of the wear track, at $\mathrm{E}=-400 \mathrm{mV}(\mathrm{SCE})$ for a) $\mathrm{NaCl} 10^{-3} \mathrm{mol.L}^{-1}$, albumin 0 g.L $\mathrm{L}^{-1}$; b) $\mathrm{NaCl} 10^{-3} \mathrm{~mol}^{-\mathrm{L}^{-1}}$, albumin 20 g. $\mathrm{L}^{-1}$; c) NaCl 1 mol.L ${ }^{-1}$, albumin 0 g.L $\mathrm{L}^{-1}$; d)NaCl 1 mol.L ${ }^{-1}$, albumin 20 g.L ${ }^{-1}$

Albumin tends to decrease $316 \mathrm{~L}$ wear due to corrosion and total wear of $316 \mathrm{~L}$, but on the contrary, total wear volume of PMMA increases in presence of albumin (Figure 12). Albumin may agglomerate around PMMA particles and thus lead to a more important third body and accelerate PMMA degradations. In presence of albumin, the wear volume of PMMA is multiplied by 8 (Figure 12). The highest degradation of PMMA in presence of albumin may lead to a largest number of particles. AFM investigations on debris size and repartition will be detailed later.
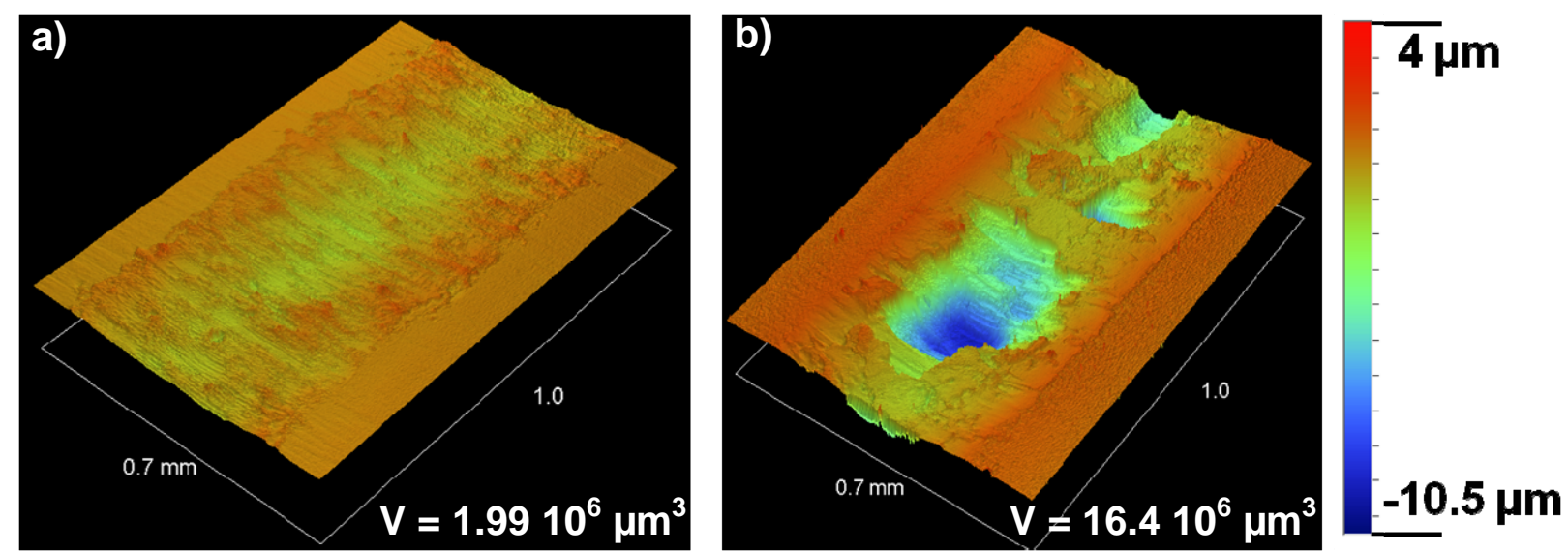

Figure 12: 3D wear track of PMMA sample $(0.7 \times 1 \mathrm{~mm})$ at $E=-400 \mathrm{mV}(\mathrm{SCE})$ for a) $\mathrm{NaCl}$ 1 mol.L ${ }^{-1}$, albumin 0 g. $\mathrm{L}^{-1}$; b) NaCl 1 mol.L ${ }^{-1}$, albumin 20 g.L ${ }^{-1}$.

Albumin plays a role in the morphology of particles. As shown on Figure 13, without albumin, the edge of the particle is more regular. In presence of albumin, edges of one particle are more difficult to determine. Moreover large particles seem to be the agglomeration of several small particles. This shape is a general tendency for tests with or without albumin and for both electrochemical conditions. The highest $\mathrm{NaCl}$ concentration promotes aggregating wear debris and/or albumin. 

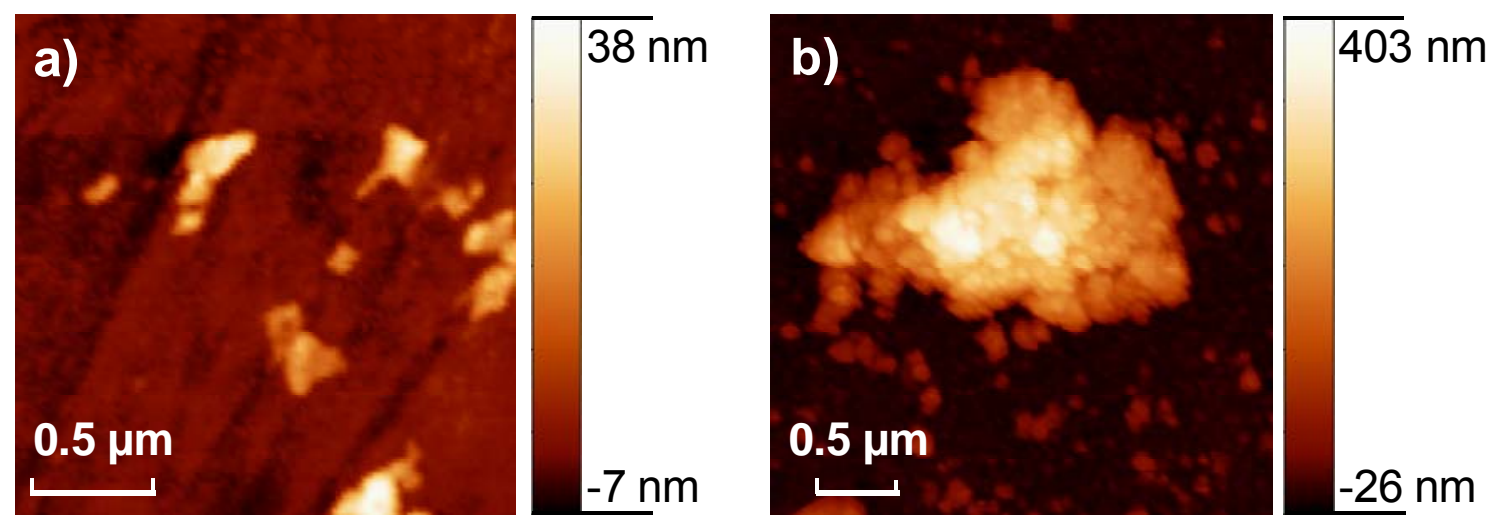

Figure 13: AFM images in height mode, zoom of particles outside of the wear track at $\mathrm{E}=$ $400 \mathrm{mV}(\mathrm{SCE})$ for a) $\mathrm{NaCl} 1 \mathrm{~mol} . \mathrm{L}^{-1}$, albumin 0 g.L ${ }^{-1}$; b) $\mathrm{NaCl} 1$ mol.L ${ }^{-1}$, albumin 1 g.L $\mathrm{L}^{-1}$

Besides, albumin slightly increases the number of pits outside the wear track. For the whole analyzed surface, in $\mathrm{NaCl} 10^{-3} \mathrm{~mol} . \mathrm{L}^{-1}$, the number goes from $0.03 \mathrm{pits} / \mu \mathrm{m}^{2}$ without albumin to $0.13 \mathrm{pits} / \mathrm{mm}^{2}$ at a concentration of $20 \mathrm{~g} . \mathrm{L}^{-1}$ of albumin, and in $\mathrm{NaCl} 1 \mathrm{~mol} . \mathrm{L}^{-1}$, the number goes from $0.05 \mathrm{pits} / \mu \mathrm{m}^{2}$ without albumin to $0.06 \mathrm{pits} / \mu \mathrm{m}^{2}$ at a concentration of $20 \mathrm{~g} . \mathrm{L}^{-1}$ of albumin. Albumin also increases the width and the depth of pits. Figure 14 shows only some profiles but they match to a mean value of depth and width. At OCP conditions, the same conclusion can be made. This observation was already noticed by Valero Vidal and Igual Muñoz [15] on 316L SS in 0.14 mol. $\mathrm{L}^{-1}$ $\mathrm{NaCl}$ with $0.5 \mathrm{~g} . \mathrm{L}^{-1}$ of albumin, after a potentiodynamic polarization (from -1.5 to $1.5 \mathrm{~V}(\mathrm{Ag} / \mathrm{AgCl})$ ). In our case, albumin $\left(20 \mathrm{~g} . \mathrm{L}^{-1}\right)$ reduces wear due to corrosion and thus acts as an inhibitor. However, the quantity of albumin may be not sufficient to protect the entire surface. Some unprotected sites can be attacked by chloride ions and they provoke pitting corrosion [15].
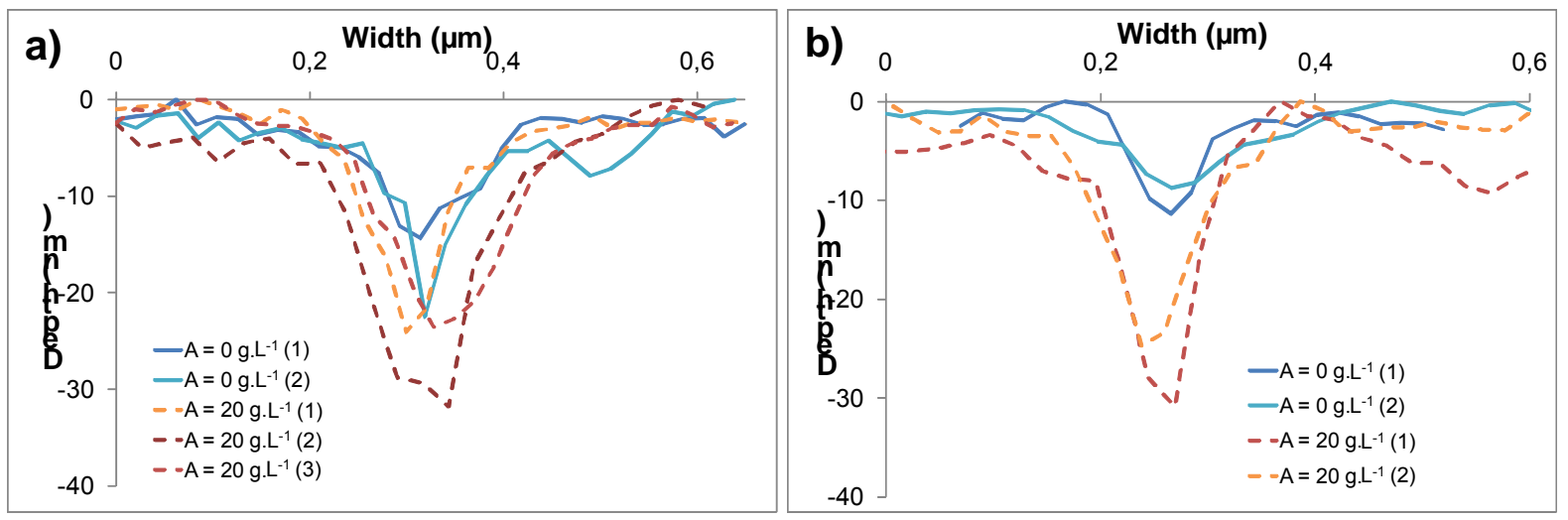

Figure 14: AFM profiles of corrosion pits at $\mathrm{E}=-400 \mathrm{mV}$ (SCE) without albumin (solid lines), and with $20 \mathrm{~g} . \mathrm{L}^{-1}$ of albumin (dashed lines) a) in $\mathrm{NaCl} 10^{-3} \mathrm{~mol}^{-\mathrm{L}^{-1}}$, at $50 \mu \mathrm{m}$ from the edge of the wear track and b) in $\mathrm{NaCl} 1 \mathrm{~mol}^{-\mathrm{L}^{-1}}$,at $500 \mu \mathrm{m}$ from the edge of the wear track

\subsection{Debris size and repartition}

Particles of polyethylene causes, most of the case, osteolysis. Thus it is a significant cause of total hip replacement loosening. However, polyethylene debris must have 'a critical size' to provoke macrophages to produce mediators of osteolysis [31]. Campbell et al. show that polyethylene submicron particles were the most clinically relevant [32]. 
For total hip joint cemented prostheses, cracks in cement mantles and wear, typically produced by fretting and friction, lead to the liberation of wear particles. The biologic responses to these particles may cause loosening of total hip prostheses. In the same way as for metals [7], Jasty et al. show that macrophages reaction occurs in response to PMMA particles but not bulk cement [33]. They show that, for mice, PMMA particles produce $\mathrm{PGE}_{2}$ and collagenase, both playing a key role in bone resorption. Horowitz et al. demonstrate in an in vitro study, that only particles that were smaller than $12 \mu \mathrm{m}$, were phagocytized by macrophages [34].

Debris, observed with AFM, are only debris 'hooked' at 316L surface. Fretting-corrosion tests are in solution and one part may be dispersed in the solution. Besides, at the end of the test and before AFM measurements, 316L sample are rinsed with distilled water. In this way, some particles can be ejected from the surface, but this step is necessary to avoid tip deterioration [35].

As shown on phase images from AFM analyses (Figure 15), we can suppose that particles are PMMA. In fact, phase images can be attributed in our case to the difference of mechanical properties. If the tip is in contact with a soft material, i.e. PMMA, the energy of the vibrations is easily dissipated, which results in a low phase value, i.e. the tip "sticks" to the surface and thus "bounces" back with a delay. If the tip is tapping a hard material, i.e. 316L SS, it will not "stick" and will easily "bounce" back, thus exhibiting higher phase value. PMMA is softer than 316L SS, so the phase will be lower for PMMA particles than for 316L SS surface [36]. As shown on Figure 15 b, PMMA particles are darker than 316L surface.
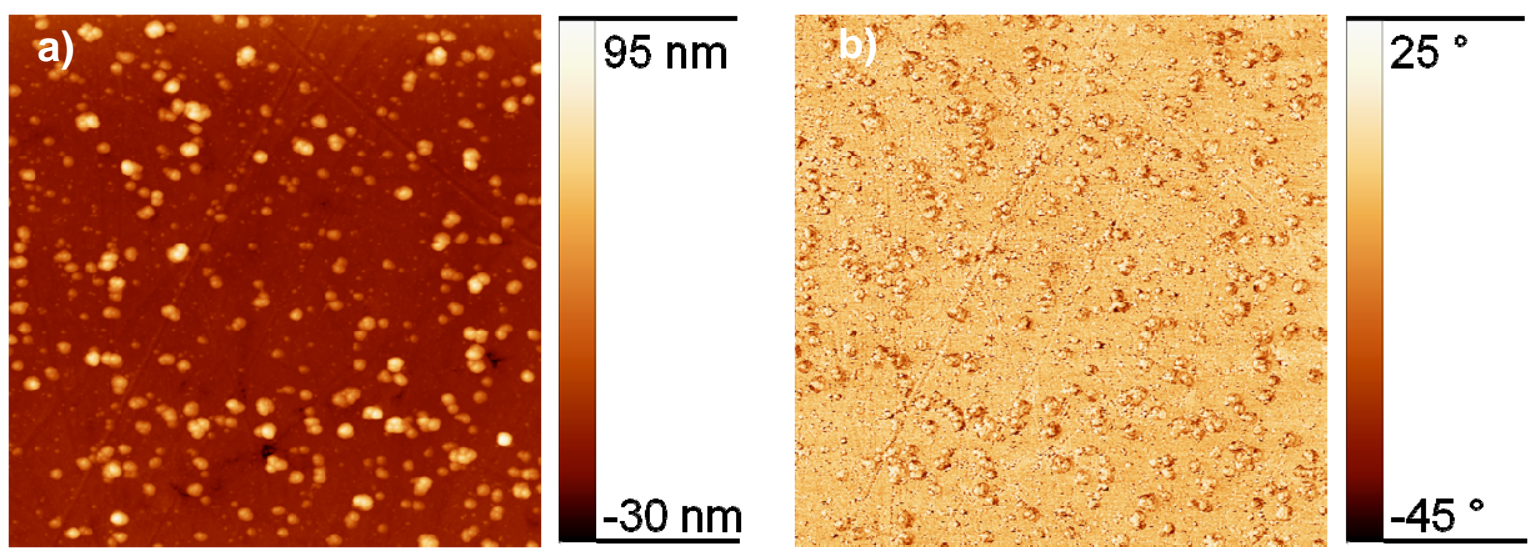

Figure 15: AFM images at $\mathrm{E}=-400 \mathrm{mV}(\mathrm{SCE})$ for $\mathrm{NaCl}^{-1} \mathrm{~m}^{-1} \mathrm{~mol} . \mathrm{L}^{-1}$, albumin $0 \mathrm{~g} . \mathrm{L}^{-1}(5 \mathrm{x}$ $5 \mu \mathrm{m})$ a) in height mode and b) in phase mode

The volume of PMMA ejected particles on 316L SS is calculated for measured surfaces and then extrapolated to the whole 316L SS surface. The hypothesis made is that the repartition of particles on 316L SS surface is homogenous. With this hypothesis, the volume of ejected particles represents about $2 \%$ of total wear volume of PMMA. This means that some particles may be on PMMA surfaces but more probably, that a large part of debris is ejected in the solution during the fretting-corrosion test. This line is related to the fact that the main part of debris, in the actual case, should be in contact with cells and/or tissues.

Thanks to the SPIPTM software, the number and the diameter of particles are extracted from AFM images. The diameter, D, (or Heywood diameter) is expressed as the diameter of a circle having an area equivalent to the shape's area:

$$
D=\sqrt{\frac{4}{\pi} * \text { Area }}
$$


The distance from the wear track is not considered, i.e. the number of particles is the total number of particles from all AFM images of same conditions. The number of particles per surface unit is distributed as a function of their diameter (Figure 16).
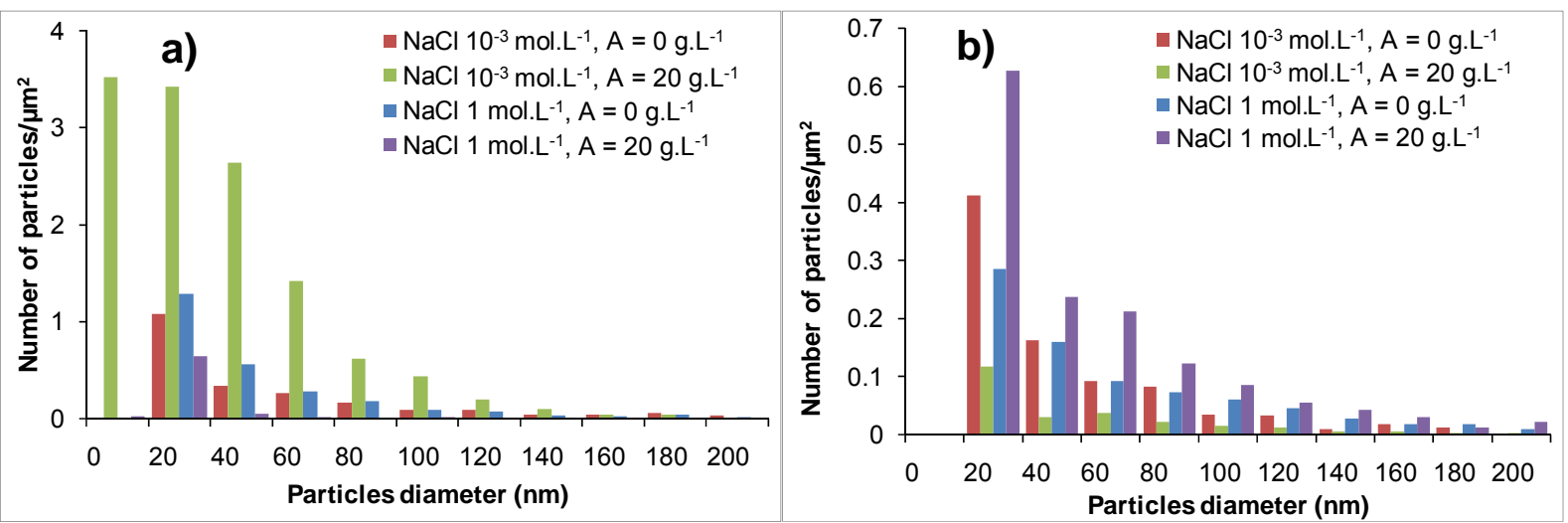

Figure 16: Repartition of all particles per surface unit, detected on analyzed surfaces at $\mathrm{NaCl}$ $10^{-3}$ and 1 mol. $\mathrm{L}^{-1}$ and with or without albumin a) at $\mathrm{OCP}$ and b) at $\mathrm{E}=-400 \mathrm{mV}$ (SCE)

The shape of histograms is the same for all conditions: about $50 \%$ of particles have a size inferior to $40 \mathrm{~nm}$, and about $80 \%$ of particles have a size inferior to $100 \mathrm{~nm}$. These histograms do not show a correlation between the number of particles and chlorides and albumin concentrations. However, the number of ejected particles per surface unit is higher at OCP conditions than at $\mathrm{E}=-400 \mathrm{mV}$ (SCE). In vivo, PMMA or 316L particles with a large range of size (from $100 \mathrm{~nm}$ to $1 \mathrm{~mm}$ ) can be observed [6, $9,11]$. No smaller PMMA or 316L particles have been observed in vivo or for simulated and in vitro tests [9]. Besides, friction-corrosion leads to a different type of PMMA wear debris. PMMA debris are more like filament [37]. More studies are made on UHMWPE particles. For total hip joint cemented prosthesis, abundant metal particles and occasional cement particles have been identified for metal-onmetal prosthesis and abundant polyethylene particles and occasional cement particles have been identified for metal-on-polyethylene prosthesis [38]. Metal and polyethylene particles are the most important generated particles. Lapcikova et al. show that in vivo polyethylene debris have an average diameter of $20 \mathrm{~nm}$ and that $80 \%$ of debris have a size between 15 and $30 \mathrm{~nm}$ [39].

Thanks to AFM analysis, we are able to observe that most of wear particles have a size inferior to $100 \mathrm{~nm}$. This size is a 'critical size' to provoke macrophages that produce mediators of osteolysis [31]. However, PMMA particles are obtained with in vitro tests and in vivo conditions are different. Bone cement is composed of and has the same mechanical properties than PMMA, but this material is more porous and thus can lead to larger particles. The most common size identified in vivo for PMMA particles is between 1 and $5 \mu \mathrm{m}$ [9]. Mitchell et al. show that the size range for the most biologically active bone cement particles is $0.1-10 \mu \mathrm{m}$. Besides, irregularly shaped particles have been found to be more biological reactive than regularly shaped ones [40].

On Figure 16, at $\mathrm{OCP}$ for $\mathrm{NaCl} 10^{-3} \mathrm{~mol} \cdot \mathrm{L}^{-1}$, albumin highly increases the number of particles, but for $\mathrm{NaCl} 1 \mathrm{~mol} . \mathrm{L}^{-1}$, albumin highly decreases the number of particles. In the same way, without albumin, the number of particles is practically the same whatever the concentration. The highest number of particles is about $20 \mathrm{~nm}$. This kind of particles, due to size, should be harmful for cells growing. At applied potential, $20 \mathrm{~g} . \mathrm{L}^{-1}$, the increase of chloride concentration leads to the increase of the number of particles. 
Finally, most of particles have a diameter inferior to $100 \mathrm{~nm}$. Submicronic particles are the 'critical size' which may lead more rapidly to osteolysis. This work has explored atomic force microscopy as a new characterization technique for wear debris for in vitro fretting-corrosion tests. In this work, only particles 'hooked' to 316L surface can be measured. However, most of particles are probably ejected from the metal surface and stay in the solution. Gladkis et al. have developed a new approach, which may be an alternative to other techniques such as filtration. This approach allows measuring the small particles with AFM. The solution is agitated to ensure the uniform repartition of particles and a small quantity of solution is deposited on a silicon substrate. The substrate is then dried under a heat lamp over $24 \mathrm{~h}$. In that way, only particles rest on substrate surface and they can be analyzed with AFM [41, 42]. This method will lead to a better repartition of nanometric particles ejected from the contact.

\section{Conclusions}

Fretting-corrosion between the femoral stem and bone cement is one of the most important causes of hip loosening. First of all, to model this contact, a cylinder of PMMA and a plane of 316L are chosen. The influence of ionic strength and albumin concentration on corrosion has been studied: albumin acts as a corrosion inhibitor.

Thanks to AFM analysis, small pits and particles can be measured. This new approach permits to determine the number of pits as a function of albumin and chloride concentration. Besides, contrary to the protective effect of albumin on corrosive wear, the increase of albumin concentration tends to promote deeper pits. Albumin may play the role of global corrosion inhibitor without fretting but not for localized corrosion. The quantity of albumin may be not sufficient to protect the entire surface and some unprotected sites can be attacked by chloride ions and provoke pitting corrosion.

Metal oxides and cement (PMMA in this study) debris are generated. Even if materials used are biocompatible in their bulk volume, small particles of these materials can involve tissues reaction. In vivo, oxides and PMMA particles of a large range of size are found but particles must have a 'critical size' to provoke tissues reactions. For PMMA, particles inferior to $12 \mu \mathrm{m}$ may cause tissues damage. The size repartition of particles demonstrates that $80 \%$ of particles have a size inferior to $100 \mathrm{~nm}$. Moreover the diameter of $20 \mathrm{~nm}$ is the usual one, i.e. very small particles that should be harmful for cells behavior. Thus cells and tissues should be modified thanks to these typical debris.

The DOE analysis shows that the number of particles that may appear for the as close as possible to the in vivo conditions is small, in comparison with the other experimental conditions. The complex interaction between chlorides and albumin concentrations is also an influent parameter for the production of particles. This point will be investigated in future works.

Additional investigations will be carried out on specific PMMA particles. In order to know the mechanical properties of debris, AFM indentation should provide interesting points about this typical material. Moreover, these debris, produced by fretting corrosion experiments, should be studied with bone cells as osteoblasts and/or osteoclasts in order to study the defective effect on bone remodeling. 


\section{References}

[1] P. Herberts, L. Ahnfelt, H. Malchau, C. Strömberg C., G.B. Andersson, Multicenter clinical trials and their value in assessing total joint arthroplasty, Clin. Orthop. Relat. Res. 249 (1989) 48-55.

[2] J. Charnley, The long-term results of low-friction arthroplasty of the hip performed as a primary intervention, J. Bone Joint Surg. Br. 54 (1972) 61-67.

[3] F. Langlais, Prothèses totales de hanche. Facteurs biologiques et mécanismes de tolérance, Conférences d'enseignement, Cahiers d'enseignement de la SOFCOT n ${ }^{\circ} 4$, Expansion scientifique française Inc, Paris, 1993, pp. 3-22.

[4] D. Suvà, V. Kindler, P. Hoffmeyer, Descellement aseptique des prothèses totales de hanche: mécanismes biologiques et perspectives de traitement, Rev. Med. Suisse 62 (2004) 2470-2473. [5] K.J. Bozic, M.D. Ries, Wear and osteolysis in Total Hip Arthroplasty, Semin. Arthroplasty 16 (2005) 142-152.

[6] E.F. DiCarlo, P.G. Bullough, The biologic responses to orthopedic implants and their wear debris, Clin. Mater. 9 (1992) 235-260.

[7] J. Cohen, Assay of foreign-body reaction, J. Bone Joint Surg. 41 (1959) 152-166.

[8] F. Escalas, J. Galante, W. Rostoker, Biocompatibility of materials for Total Joint Replacement, J. Biomed. Mater. Res. 10 (1976) 175-195.

[9] J.A. Savio, L.M. Overcamp, J. Black, Size and shape of biomaterial wear debris, Clin. Mater. 15 (1994) 101-147.

[10] H.G. Willert, G. Buchhorn, U. Buchhorn, M. Semlitsch, US Dept of Commerce, Washington DC, Ch. Tissue Response to Wear Debris in Artificial Joints, , Implant Retrieval: Material and Biological Analysis, National Bureau of Standards Spec. Pub. 601, 1981, pp. 239-267.

[11] J. Charnley, Acrylic cement in orthopaedic surgery, Br. J. Surg. 57 (1970) 874.

[12] Pellier J., Geringer J., Forest B., Fretting-corrosion between 316L SS and PMMA: influence of ionic strength, protein and electrochemical conditions on material wear. Application to orthopedic implants., Wear 2011;271:1563-1571.

[13] Pellier J., Geringer J., Forest B., Ionic strength effect during fretting-corrosion on a « model » contact: PMMA-stainless steel. Application to orthopaedic implants., Presses polytechniques et universitaires romandes, 2011, Ch. in press.

[14] Afonso M.L.C.A., Villamil Jaimes R.F.V., Arêas E.P.G., Capri M.R., Oliveira E., Agostinho S.M.L., The influence of albumin on the anodic dissolution of chromium present in UNS S31254 stainless steel in chloride environment, Colloids Surf. A Physicochem. Eng. Asp. 2008;317:760-763.

[15] Valero Vidal C., Igual Muñoz A., Electrochemical characterisation of biomedical alloys for surgical implants in simulated body fluids, Corros. Sci. 2008;50:1954-1961.

[16] Hiromoto S., Mischler S., The influence of proteins on the fretting-corrosion behaviour of a Ti-6Al-4V alloy, Wear 2006;261:1002-1011.

[17] Watson S.W., Friedersdorf F.J., Madsen B.W., Cramer S.D., Methods of measuring wearcorrosion synergism, Wear 1995;181-183:476-484.

[18] Jiang J., Stack M.M., Neville A., Modelling the tribo-corrosion interaction in aqueous sliding conditions, Tribol. Int. 2002;35:669-679.

[19] Rubin P.J., Leyvraz P.F., Rakotomanana L.R., Intérêt de la modélisation numérique dans l'évaluation pré-clinique d'une prothèse fémorale de la hanche, Maîtrise Orthopédique 2000;93:22-27.

[20] Geringer J., Forest B., Combrade P., Fretting-corrosion of materials used as orthopaedic implants, Wear 2005;259:943-951. 
[21] Geringer J., Forest B., Combrade P., Wear of poly (methyl methacrylate) against a metallic surface in dry conditions, Polym. Eng. Sci. 2007;47:633-648.

[22] ASME. Surface texture surface roughness waviness and lay. ASME B46.1 2002, $110 \mathrm{p}$.

[23] Horcas I., Fernandez R., Gomez-Rodriguez J.M., Colchero J., Gomez-Herrero J., Baro A.M., WSxM: a software for scanning probe microscopy and a tool for nanotechnology, Rev. Sci. Instrum. 2007;78:1-8.

[24] Karimi S., Nickchi T., Alfantazi A., Effects of bovine serum albumin on the corrosion behaviour of AISI 316L, Co-28Cr-6Mo, and Ti-6Al-4V alloys in phosphate buffered saline solutions, Corros. Sci. 2011;53:3262-3272.

[25] Landolt D., Corrosion et chimie de surfaces des métaux, Presses polytechniques et universitaires romandes, 1997.

[26] Iwabuchi A., Lee J.W., Uchidate M., Synergistic effect of fretting wear and sliding wear of Co-alloy and Ti-alloy in Hanks' solution, Wear 2007;263:492-500.

[27] Hoar T.P., Jacob W.R., Breakdown of passivity of stainless steel by halide ions, Nature 1967;216:1299-1301.

[28] Hong M.H., Pyun S.I., Corrosive wear behaviour of 304L stainless steel in $1 \mathrm{~N} \mathrm{H}_{2} \mathrm{SO}_{4}$ solution. Part 2: Effect of chloride ion concentration, Wear 1991;147:69-78.

[29] Malik A.U., Mayan Kutty P.C., Siddiqi N.A., Andijani I.N., Shahreer A., The influence of pH and chloride concentration on the corrosion behaviour of AISI 316L steel in aqueous solutions, Corros. Sci. 1992;33:1809-1827.

[30] Peters T., Advances in Protein Chemistry, Volume 37, Academic Press, 1985, Ch. Serum albumin, pp. 161-237.

[31] Green T.R., Fisher J., Stone M., Wroblewski B.M., Ingham E., Polyethylene particles of a 'critical size' are necessary for the induction of cytokines by macrophages in vitro, Biomaterials 1998;19:2297-2302.

[32] Campbell P., Ma S., Yeom B., McKellop H., Schmalzried T.P., Amstutz H.C., Isolation of predominantly submicron-sized UHMWPE wear particles from periprosthetic tissues, J. Biomed. Mater. Res. 1995;29:127-131.

[33] Jasty M., Jiranek W., Harris W., Acrylic fragmentation in Total Hip Replacements and its biological consequences, Clin. Orthop. Relat. Res. 1992;285:116-127.

[34] Horowitz S., Doty S., Lane J., Burstein A., Studies of a mechanism by which the mechanical failure of polyethylmethacrylate leads to bone resorbtion, J. Bone Joint Surg. 1993;75:802-813.

[35] University of Cambridge, Dissemination of IT for the Promotion of Materials Science (consulté en mai 2011), www.doitpoms.ac.uk (consulté en juillet 2011).

[36] O'Neil K.D., Semenikhin O.A., AFM phase imaging of thin films of electronically conducting polymer polybithiophene prepared by electrochemical potentiodynamic deposition, Russ. J.

Electrochem. 2010;46:1345-1352.

[37] Geringer J., Atmani F., Forest B., Friction-corrosion of AISI 316L/bone cement and AISI 316L/PMMA contacts: Ionic strength effect on tribological behaviour, Wear 2009;267:763-769.

[38] Howie D.W., Tissue response in relation to type of wear particles around failed hip arthroplasties, J. Arthroplasty 1990;5:337-348.

[39] Lapcikova M., Slouf M., Dybal J., Zolotarevova E., Entlicher G., Pokorny D., Gallo J., Sosna A., Nanometer size wear debris generated from ultra high molecular weight polyethylene in vivo, Wear 2009;266:349-355. 
[40] Fang H.W., Su Y.C., Huang C.H., Yang C.B., Influence of biological lubricant on the morphology of UHMWPE wear particles generated with microfabricated surface textures, Mater. Chem. Phys. 2006;95:280-288.

[41] Gladkis L.G., Li R.W., Scarvell J.M., Smith P.N., Timmers H., Exploration of the size, shape and abundance of UHMWPE wear particles using atomic force microscopy, Wear 2009;267:632-638.

[42] Gladkis L.G., Timmers H., Scarvell J.M., Smith P.N., Detailed three-dimensional size and shape characterisation of UHMWPE wear debris, Wear 2011;270:455-463.

[43] Box G.E.P., Hunter W.G., Hunter J.S., Statistics for experimenters, John Wiley, 1978. 